\title{
MASTER
}

\section{CATARACT HYDROELECTRIC DEVELOPMENT EXPANSION STUDY}

PREPARED UNDER COOPERATIVE

AGREEMENT N॰ EW-78-F-07-1796

FOR THE U.S. DEPARTMENT OF ENERGY

JANUARY 1979

\section{CMP Central Maine Power Company}

GENERAL OFFICE, EDISON DRIVE, AUGUSTA, MAINE 04336

TATMSTIPPETTS-ABBETT-McCARTHY-STRATTON

ENGINEERS AND ARCHITECTS, NEW YORK 


\section{DISCLAIMER}

This report was prepared as an account of work sponsored by an agency of the United States Government. Neither the United States Government nor any agency Thereof, nor any of their employees, makes any warranty, express or implied, or assumes any legal liability or responsibility for the accuracy, completeness, or usefulness of any information, apparatus, product, or process disclosed, or represents that its use would not infringe privately owned rights. Reference herein to any specific commercial product, process, or service by trade name, trademark, manufacturer, or otherwise does not necessarily constitute or imply its endorsement, recommendation, or favoring by the United States Government or any agency thereof. The views and opinions of authors expressed herein do not necessarily state or reflect those of the United States Government or any agency thereof. 


\section{DISCLAIMER}

Portions of this document may be illegible in electronic image products. Images are produced from the best available original document. 


\section{CATARACT HYDROELECTRIC DEVELOPMENT EXPANSION STUDY}

PREPARED UNDER COOPERATIVE

AGREEMENT $\mathrm{N}^{\circ}$ EW-78-F-07-1796

FOR THE U.S. DEPARTMENT OF ENERGY

JANUARY 1979
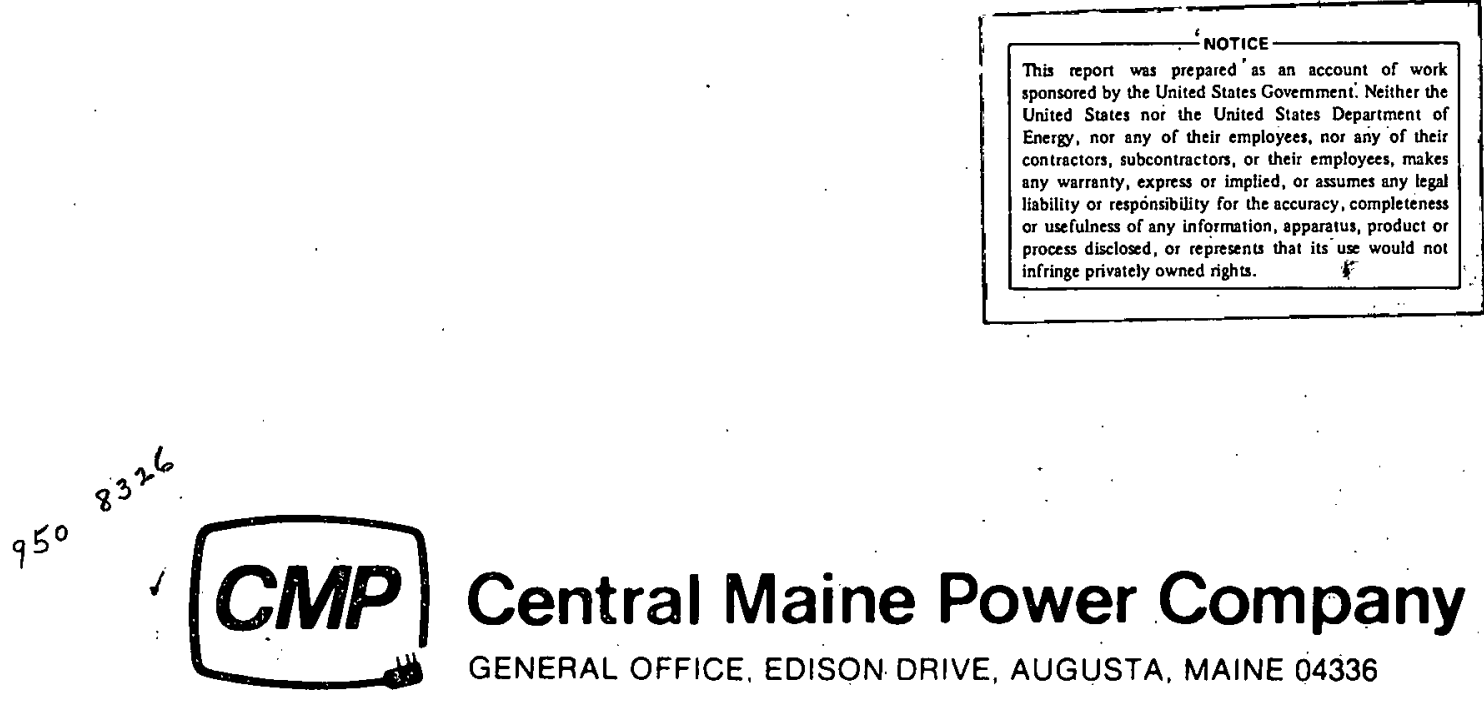

\section{Central Maine Power Company}

GENERAL OFFICE, EDISON DRIVE, AUGUSTA, MAINE 04336

${ }_{95} 1^{0^{0^{5}} /}$ TAMS 
CATARACT HYDROELECTRIC DEVELOPMENT

EXPANSION STUDY

CONTENTS

$\underline{\text { Page }}$

A. SUMMARY AND RECOMMENDATIONS $\ldots \ldots \ldots \ldots \ldots \ldots \ldots \ldots \ldots \ldots \ldots \ldots \ldots$

B. GENERAL $\ldots \ldots \ldots \ldots \ldots \ldots \ldots \ldots \ldots \ldots \ldots \ldots \ldots \ldots \ldots \ldots \ldots \ldots \ldots \ldots \ldots$

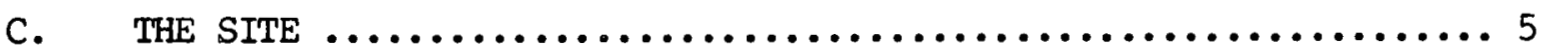

I. Description of Existing Project $\ldots \ldots \ldots \ldots \ldots \ldots \ldots \ldots \ldots \ldots \ldots$

II. Present Operation $\ldots \ldots \ldots \ldots \ldots \ldots \ldots \ldots \ldots \ldots \ldots \ldots \ldots \ldots \ldots$

III. History $\ldots \ldots \ldots \ldots \ldots \ldots \ldots \ldots \ldots \ldots \ldots \ldots \ldots \ldots \ldots \ldots \ldots \ldots \ldots$

IV. Hydrology $\ldots \ldots \ldots \ldots \ldots \ldots \ldots \ldots \ldots \ldots \ldots \ldots \ldots \ldots \ldots \ldots \ldots \ldots$

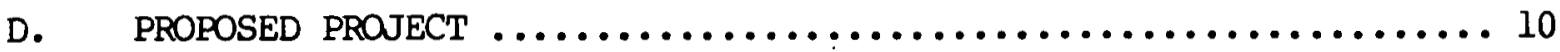

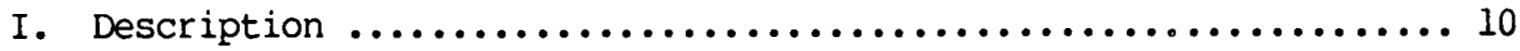

II. Transmission Lines $\ldots \ldots \ldots \ldots \ldots \ldots \ldots \ldots \ldots \ldots \ldots \ldots \ldots \ldots \ldots \ldots$

III. Construction Procedures and Schedule ................... 14

IV. Safety Assessment $\ldots \ldots \ldots \ldots \ldots \ldots \ldots \ldots \ldots \ldots \ldots \ldots \ldots \ldots \ldots \ldots \ldots$

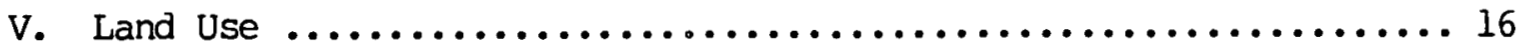

VI. Regulatory Requirements $\ldots \ldots \ldots \ldots \ldots \ldots \ldots \ldots \ldots \ldots \ldots \ldots \ldots \ldots$

E. ENERGY PRODUCTION $\ldots \ldots \ldots \ldots \ldots \ldots \ldots \ldots \ldots \ldots \ldots \ldots \ldots \ldots \ldots \ldots \ldots$

I. Capacity Addition $\ldots \ldots \ldots \ldots \ldots \ldots \ldots \ldots \ldots \ldots \ldots \ldots \ldots \ldots \ldots \ldots$

II. Proposed Operation $\ldots \ldots \ldots \ldots \ldots \ldots \ldots \ldots \ldots \ldots \ldots \ldots \ldots \ldots \ldots$

III. Energy Generation $\ldots \ldots \ldots \ldots \ldots \ldots \ldots \ldots \ldots \ldots \ldots \ldots \ldots \ldots \ldots \ldots$

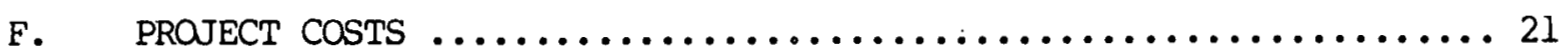

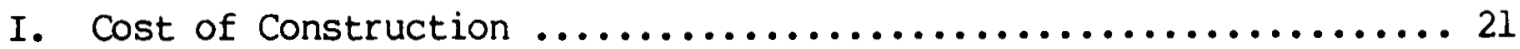

II. Cost of Operation and Maintenance $\ldots \ldots \ldots \ldots \ldots \ldots \ldots \ldots \ldots \ldots$. $\ldots \ldots \ldots$ 


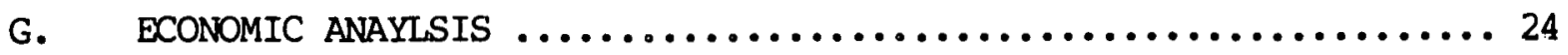

H. ENVIRONMENTAL ASSESSMENT $\ldots \ldots \ldots \ldots \ldots \ldots \ldots \ldots \ldots \ldots \ldots \ldots \ldots \ldots \ldots \ldots \ldots \ldots \ldots$

I. Description of Existing Environment $\ldots \ldots \ldots \ldots \ldots \ldots \ldots \ldots \ldots \ldots, 27$

II. Effects of Construction and Operation $\ldots \ldots \ldots \ldots \ldots \ldots \ldots \ldots . \ldots 30$

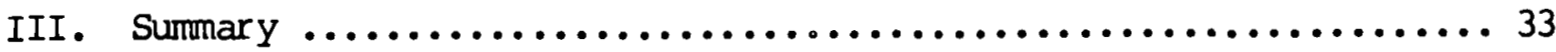

IV. References $\ldots \ldots \ldots \ldots \ldots \ldots \ldots \ldots \ldots \ldots \ldots \ldots \ldots \ldots \ldots \ldots \ldots \ldots, 33$

\section{LIST OF FIGURES}

\section{Figure Title}

$1 \quad$ Location Map

2 Detail Map - Dams and Powerhouse Area

3 Powerhouse and Dam - Plan, Elevation and Sections

4 Powerhouse Plan and Sections

5 West Channel Dam - Plan and Sections

6 Bradbury and Springs Dams - Plan and Sections

$7 \quad$ Flow Duration Curve

8 New Powerplant - Location Plan

9 New Powerplant - Arrangement and Details

10 Electrical One Line Diagram

11 Project Design and Construction Schedule

\section{LIST OF TABLES}

Table Title

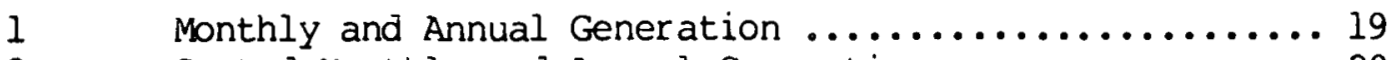

2 Sorted Monthly and Annual Generation .............. 20

3 Summary of Preliminary Cost Estimate .............. 23

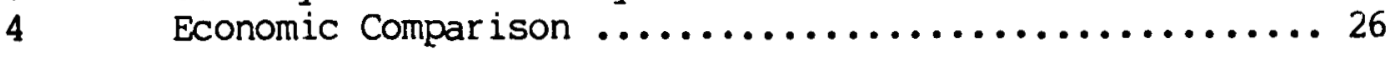

\section{APPENDICES}

I. Alternative Project Studies

II. Alternative Capacity, Energy, Cost Studies

III. Geological Reconnaissance and Subsurface Explorations Log 
CONTENTS (Cont'd)

LIST OF APPENDICES FIGURES

Eigure Title

A III-1 Bore Hole Location Map

Sub-surface Exploration Logs (2 pages)

LIST OF APPENDICES TABLES

Table

Title

A II-1

Alternate Studies - Capacity vs Energy 


\section{A. SUMMARY AND RECOMMENDATIONS}

The Cataract Hydroelectric Development is part of the Central Maine Power Company's generating system. The existing power plant and dam was constructed in 1937-38 and has been operated continually since that date. This unit is a vertical shaft Kaplan type machine with a rated output of $6650 \mathrm{~kW}$ at a design head of 44 feet. Maximum output is $8000 \mathrm{~kW}$.

In September 1978 the Central Maine Power Company entered into a cooperative agreement with the U.S. Department of Energy to perform a feasibility study of the potential for expansion of this existing project. Central Maine Power engaged Tippetts-Abbett-McCarthy-Stratton, Engineers and Architects, as sub-contractors to assist in this feasibility study.

Results of the study indicate the following:

The available head and unused flow at the Cataract Project will support an additional $6250 \mathrm{~kW}$ of generating capacity. Due to physical and hydraulic constraints in the existing east channel site, the preferred location for this additional capacity is in the west channel dam near the Saco Tanning intake. The estimated gross plant investment cost of this plant would be $\$ 5,230,000$ at present day costs. If a fishway is required the investment is estimated to be $\$ 5,730,000$.

Based on the analysis of 60 years of historical flow records this capacity addition would generate an average of $15,910,000 \mathrm{~kW}$ hours per year.

Economic analysis shows that the preferred turbine-generator package is two 2.5 meter horizontal shaft, standardized design, adjustable blade, tube type turbines with matching generators.

However, the economic advantage of this package as compared to a comparable 3.00 meter turbine package was small and less than the potential magnitude of error of the preliminary cost estimate. Thus at the final design stage the selected turbine size may be varied to suit updated cost and economic data analysis. 
This feasibility study indicates that redevelopment of the Cataract site as described above is a marginally economic proposition which might offer some savings, over the life of the unit; however, two significant questions remain unanswered. First, will a fishway be required as part of the redevelopment? Second, can a new or renewed fifty year FERC license be obtained for the Cataract site?

Central Maine Power Company intends to make more detailed studies to refine specific aspects of the plant, explore the question of the fishway with the appropriate state and federal agencies and persue the possibility of acquiring the Saco Tanning water rights. If the above mentioned items can be satisfactorily resolved the Company would expect to proceed with the application for a new fifty year license from the Federal Energy Regulartory Commission. 
B. GENERAL

on September 1, 1978 the Central Maine Power Company (CMP) entered into co-operative agreement No. EW-78-F-07-1796 with the U.S. Department of Energy (DOE) to perform a feasibility study of the potential for expansion of their existing Cataract Hydroelectric Plant. CMP engaged TippettsAbbett-McCarthy-Stratton (TAMS), Engineers and Architects, as subcontractors to assist in this feasibility study.

CMP is a public utility operating in the state of Maine. Its service area covers 10,600 square miles and has a population of 700,000, or samewhat more than two-thirds of the population of the state. As of December 31, 1977, the company was serving 327,336 residential, 38,728 general service, and 403 other customers.

The Company is conmitted to serving the energy needs of its customers. In fulfulling this commitment, it has placed particular emphasis on developing Maine's indigenous energy resources. This emphas is is demonstrated by CMP's current reconstruction of the Brunswick project (FERC Docket \#P2834), possible further development of the Upper Kennebec River, restoration of inoperable equipment at Deer Rips Station, upgrading of capacity at Gulf Island Station as well as participatin in this and other feasibility studies.

CMP owns 24 hydroelectric generating stations and leases one with an aggregate net capability of $301,850 \mathrm{~kW}$, three oil-fired steam-electric with an estimated net capability of $406,320 \mathrm{~kW}$ and five internal combustion generating facilities with an estimated net capability of $50,850 \mathrm{~kW}$. The total capacity of all wholly owned generating stations is $759,020 \mathrm{~kW}$. CMP also has joint ownership entitlements in nuclear units amounting to an additional $362,860 \mathrm{~kW}$ for a total system capability of $1,121,880 \mathrm{~kW}$.

The existing Cataract hydroelectric power plant forms part of this system and presently has a maximum capacity of $8,000 \mathrm{~kW}$ and generates approximately 45,000 MW hrs. in an average water year. 
The Company's total net sales for 1977 were 5,572,502,246 kwh of which $43,254,910 \mathrm{kWh}$ were purchased from small hydro operators who had excess energy. 


\section{THE SITE}

\section{Description of Existing Project}

The existing Cataract project (FERC licensed project No. 2528) is located in Southern Maine in the City of Saco, on the Saco River about three miles from its mouth. The project is near the Portland, Maine load center. Its relationship to the surrounding area is indicated in Figure 1.

The Cataract Project consists of the Cataract Dam and Hydroelectric Station located in the east channel of the Saco River, West Channel dam in the west channel, and Bradbury and Springs Dam, in the upstream west and east channels, respectively. Figure 2 shows the location of these features in relation to each other.

The following is a brief description of each of the various parts of the project. The Cataract Dam and power plant (Figure 3 and 4), located in the City of Saco consists of an overflow section, a gate section and an intake section. The overflow section is a concrete gravity dam with a fixed crest at Elevation 40. It is 90 feet long with four feet of hinged type flashboards. A bridge is provided for servicing the flashboards. A vertical lift Broome type gate, 20 feet wide by 15 feet high is installed in the gate section. The sill of the gate is at Elevation 29. The intake section is 49.25 feet long and is equipped with racks and two intake openings. One opening is 16.4 feet wide by 17.6 feet high and contains a slide type gate and the other opening is 14 feet wide by 17.6 feet high with a car-wheel type gate.

The powerhouse substructure, approximately 37 feet by 53 feet, houses a 9,000 H.P. Smith-Kaplan water wheel at a rated head of 44 feet. The draft tube is at an angle of about $20^{\circ}$ to the intake, and extends 30 feet downstream from the substructure where it discharges into tide water. The operations head normally varies between 37 and 44 feet depending on tide level and unit discharge. Two gates, each 15 feet wide by 12.8 feet high are installed at the downstream end of the draft tube. The powerhouse superstructure, constructed of structural steel frame and brick, contains 
a 6,650 kW generator and associated equipment. A 60-ton capacity powerhouse crane is installed to service the unit. The power generated at the station is fed by underground conduits to a substation located in the station's yard on Factory Island.

Factory Island separates the east and west channels of the river. West Channel Dam (Figure 5) is located in the Cities of Saco and Biddeford. It consists of two overflow sections, fishway and a gate section. The first spillway section is a gravity type of stone masonry construction capped with concrete. This section, which extends from the west bank 193 feet to an angle point and 44.5 feet from the angle point to a fishway, has a fixed crest at Elevation 40.5 with 4.5 feet of pin-type flashboards.

The fishway section is 16.5 feet wide and abuts the gate section which contains a tainter gate, 20 feet wide by 15 feet high. The sill of the gate is at Elevation 30 .

The normal full pond created by Cataract and West Channel Dams is at elevation 44, covers an area of about 14 acres and extends upstream approximately 0.3 miles to Springs and Bradbury Dams. The Saco River upstream from Factory Island again divides into two channels to create Springs Island. Bradbury Dam is located in the west channel and Springs Dam in the east channel.

Bradbury Dam (Figure 6) in the City of Biddeford consists of two concrete gravity overflow sections one on each side of a gate structure. The first section extending 141 feet from the west shore and has a fixed crest at elevation 47.7 with 1.7 feet of pin-type flashboards. The gate structure with a sill at elevation 36.2, contains a tainter gate, 20.3 feet wide by 13.5 feet high. The gate is remotely controlled from the cataract Power plant control room. The second overflow section extends from the gate structure to Springs Island. This section is 38 feet long, with a fixed crest at elevation 47.7 and has 1.7 feet of pin-type flashboards. 
Springs Dam (Figure 6) located in the Cities of Biddeford and Saco, consists of a concrete gravity overflow section and two gate sections. The overflow section extends 117.5 feet from the east shore to the first gate section. It has a crest at elevation 47.7 topped by 1.5 feet of pin-type flashboands. The first gate structure has four gate openings with sills at elevation 39.2. Three openings contain tainter gates 16 feet wide by 11 feet high. The second gate with an invert at elevation 39.2 contains three submerged gates each 8 feet wide by 6 feet high. This gated section extends to Springs Island.

The normal full pond upstream of Bradbury and the Springs Dam (elevation 49.2) has a surface area of about 359 acres, and extends upstream approximately 9.3 miles to the Skelton Hydroelectric Development. Usable storage is 750 acre feet.

\section{Present Operation}

The existing Cataract power plant has a maximum discharge capability of 2600 cfs for a maximum power output of $8000 \mathrm{~kW}$. Other water rights, purchased process water, fish ladder releases and estimated leakage at gates and flashboards total about $300 \mathrm{cfs}$. In periods of low flow, use of the 750 acre feet of storage behind Springs and Bradbury Dams permits generation on a part-day basis and enables the power plant to operate over the entire low flow range. This storage is also used to reregulate re leases from the upstream Skelton Power Plant which discharges 3600 cfs at full load. Thus, the project is essentially operated as a run-of-river plant over a flow range in the river of $300 \mathrm{cfs}$ to $2900 \mathrm{cfs}$, with the added benefit of being able to generate at the time of day best suited to system demand during the low flow periods. From the flow duration curve (Figure 7) a flow of $2900 \mathrm{cfs}$ is exceeded approximately $40 \%$ of the time.

The average annual energy produced is approximately 45,000 MW hours per year. 


\section{History}

Power was originally developed at this site in 1653 to operate a sawmill. This mill was burned by Indians in 1675. A second mill was built in 1680 and was probably destroyed again by the Indians prior to 1690 .

William Pepperell of colonial fame purchased the site in 1716 and sold two quarters to Humphrey Scammon and Nathaniel Ware. These quarter shares were acquired by Colonel Thomas Cutts in 1774. He and Pepperell each owned one-half of the water rights and half of Factory Island. By 1821, an iron foundry, two sawmills and various machine shops were operating from power developed at the site. The York Manufacturing Company acquired all the water rights in 1831. The Saco Water Power Company purchased these water rights in 1840 with the exception of eleven mill powers. The Pepperell Manufacturing Company, successor to the Saco Water Power Company, sold its dams and water rights to Cumberland County Power and Light Company with the exception that they reserved the right to up to 10 million gallons of water per day for use in their plant at an agreed price. The eleven mill powers formerly owned by York Manufacturing Company are now owned by Saco Tanning Company.

Construction of the present development started in 1937 and was completed in 1938. Central Main Power Company acquired the development through merger with Cumberland County Power and Light Company in 1942.

\section{Hydrology}

The Saco River at the Cataract Project has a catchment area of 1,703 square miles. The river is characteristic of New England streams in that flows are generally high in the later winter and spring and minimum in the late summer and fall. The maximum flow of record was 63,000 cfs and occurred in 1936. Five other power developments exist on the river but each development has only sufficient storage for daily regulation. There is no seasonal storage in the basin. The flow duration curve at the Cataract Project is shown as Figure 7. It can be seen that the median flow is 2200 cfs while the calculated average flow is 3497 cfs. 
The duration curve was derived by extending the records at the now abandoned Salmon Falls gage by correlation from the 60 years of record at the upstream Cornish gage. The extended Salmon Falls record was then adjusted by the ratio of the drainage areas to give the flows at the Cataract Project. 


\section{PROPOSED PROJECT}

\section{Description}

It is proposed to expand the existing project by adding two 2.5 meter tube-type turbine-generators with a rated capacity of $6,240 \mathrm{~kW}$ in a new power plant. The new power plant will be located in the West Channel of the Saco River adjacent to Factory Island. Figure 8 shows the location of the proposed powerhouse in relation to the existing project. It will connect to the west Channel Dam by a new concrete open flume. An excavated tailrace channel will connect the powerhouse to the downstream river channel.

The methods of expanding the project included an investigation of the possibility of upgrading the existing plant. Initial studies have indicated that the power output of the existing turbine can be increased by replacing rotating parts of improved design, but the economics dictate the work be performed during the next major overhaul of the unit after the new plant is complete.

A detailed description of the proposed expansion project follows. A general arrangement of the new plant is shown on Figure 9.

\section{Available Head}

In reviewing the hydraulics of the west channel it was found that a shallow section just upstream of the Main street bridge forms a nydraulic control at low tide. The studies also indicated that with high flow in the west Channel the tailwater above the bridge will vary between elevation +4 feet and +6 feet at low and high tide, respectively, with a mean elevation of +5 feet.

Headwater will be the existing pond formed by the west Channel and Cataract Dams. The normal level of this pond is at Elevation +44 feet.

Therefore, an average design head of 39.0 feet is available for a new plant in the West Channel. 


\section{Headworks}

The existing West Channel Dam will be the headworks for the flume connecting to the powerhouse. The length of dam between the existing gate structure and Factory Island will be removed and replaced by the entrance to the flume.

In removing the portion of the existing dam some flashboards and existing spillway area will be removed. To provide the same flood discharge capacity it is proposed to install at least an equivalent length of spillway in the flume wall. Flashboards would also be added to maintain the present upstream water levels.

\section{Flume}

The flume will convey river flows from the West Channel Dam pond to the powerhouse. It will be about 200 feet in length and will be located in the river adjacent to the Factory Island bank. The flume will be rectangular with a width of 40 feet and at the maximum depth of 23 feet, will have ample flow capacity.

Stop logs will be provided at the upstream end of the flume so flow can be stopped for maintenance purposes. Trash racks will be provided at the downstream end of the flume to prevent debris from entering the turbines. Provisions for cleaning equipment and trash disposal will be included.

\section{Powerhouse}

The powerhouse will be located immediately downstream of the trash rack structure. It will be constructed of reinforced concrete and has been sized to house two 2.50 meter horizontal turbine and all necessary electrical and mechanical equipment. 
The powerhouse will be approximately 65 feet long, 40 feet wide. The foundation will be excavated in sound quartzite which will provide a suitable bearing capacity. The roof will be at Elevation +38 feet which is set by access requirements and is well above the level of the flood of record.

Access will be from existing roads on Factory Island. Erection and maintenance of the equipment will be through hatches provided in the power plant roof using mobile cranes. Provision for standing the crane immediately adjacent to the power plant is provided. Access for routine inspection by operating personnel will be provided by an independent doorway and ship ladder type stairs.

Operating and routine surveillance of the plant will be performed remotely from the central room at the existing Cataract Plant.

\section{Generating Equipment}

Two 2.5 meter horizontal shaft, standarized design, adjustable blade, tube type turbines are provided, each having a design head of 39 feet. A speed increasing gearbox will be installed between the turbine and generator in order to reduce generator size and weight. The generators will have a capacity of $6,240 \mathrm{~kW}$ at design head and best turbine efficiency which will rise to $7,900 \mathrm{~kW}$ at maximum head and maximum turbine power. Generation will be at $4.16 \mathrm{kV}$.

All necessary mechanical and electrical controls and auxiliaries will be included as part of the standarized design. Remote control equipment will be provided for operating the plant from the Cataract Plant control room. .

A butterfly valve will be provided immediately upstream of each unit and a draft tube bulkhead gate immediately downstream to facilitate unit de-watering.

An electrical one line diagram of the new plant is shown as Figure 10. 


\section{Tailrace}

The tailrace channel will be open cut, unlined and approximately 230 feet long. Excavation will be in sound quartzite down to elevation -1l feet at the powerhouse. At the downstream end, excavation will terminate at the +2 foot contour. The cross section of the channel was designed to maintain an approximately uniform velocity. Mean tailwater elevation will be +5 feet.

\section{Revision to the Existing Project}

Inquiries were made of the manufacturer of the existing turbine regarding the possibility of increasing its power output. They reported that two methods of upgrading were feasible, new runner blades or alternately a new runner hub with new blades.

Preliminary studies, summarized in Appendix I, indicated that this possibility appears attractive, however, it was concluded that upgrading of this unit could best be accomplished after the new project is completed, and during the unit's next major overhaul. Prior to making a final decision to upgrade this unit a detailed review of all elements of the machine, its controls and transmission system would be required to ensure that all costs have been included in the estimate and to ensure that all components will operate reliably. The last major overhaul of this machine was performed in 1972. From prior experience the next major overhaul is not expected to occur before 1990 .

\section{Transmission Lines}

Existing transmission lines and sub-stations on Factory Island form part of the Central Maine Power Companies power distribution system.

It is proposed that the new units will generate at $4.16 \mathrm{kV}$ with transmission lines in buried cable duct to a step-up transformer located immediately adjacent to the powerplant. From this point transmission will be by $34 \mathrm{kV}$ line either to the Factory Island sub-station about two tenth 
mile from the step-up transformer, or to a distribution line located approximately the same distance away.

\section{Construction Procedures and Schedule}

A most important step in constructing this project is the selection of qualified contractors. It is proposed that the contractors be selected by competitive bidding, preselecting those who can demonstrate that they are qualified to manufacture the equipment and those that are qualified to construct the project.

Itens to be considered in preselecting equipment manufacturers are prior experience in design, manufacture, on schedule delivery, erection supervision, and ability to meet design performance criteria.

For on site construction the contractor should be experienced in heavy civil engineering projects with emphasis on rock excavation adjacent to existing structures and placement of materials in a confined area with difficult access. For erection of equipment, it may be necessary for the contractor to have a sub-contractor experienced in the erection of heavy rotating machinery.

Some careful construction scheduling will be necessary to complete most of the work during the low flow season. This includes removal of the small section of the existing west Channel Dam so as to avoid interrupting the water supply to the Saco Tannery. This intake is located at the north abutment of the dam. It is proposed to schedule this work to coincide with the annual two week period of factory shut down in the summer. Because of the short time available for this work, a cofferdam will probably not be possible. However, as this is a period of low. river flow, judicious operation of the storage capacity above the Springs and Bradbury Dams and the Skelton Project may allow the work to be achieved in the scheduled time by lowering the water level in the forebay pond.

Further careful planning will be required for rock excavation that will be required below the extreme high tide elevation in the tailrace channel. Sequential drilling, firing and mucking on the low tide during 
the low flow period in the river may be feasible as the downstream end of the tailrace channel is at elevation +2.0 feet.

A schedule for construction of the project is shown on Figure 11. The schedule indicates that the project can be ready to generate energy approximately 30 months after receiving a FERC license. No period of time has been shown for obtaining a license as the time required cannot be reliably predicted.

In order to gain the maximum economic advantage as new generating capacity the best time to have the units start commercial operation is just prior to the start of the pool defined power year (i.e. November). The schedule has been set to meet this commercial operation date.

This schedule has been based on conservative assumptions, i.e.

a) Winter weather and streamflow conditions will be such as to make outside construction work in the river channel from January 1 to June 1 uneconomical.

b) Although domestic manufacturers indicate a much faster delivery schedule for turbines and generators than shown, the schedule was set so as not to preclude foreign manufacturers because of possible longer shipping times, and also to ensure timely delivery of embedded parts for site erection.

\section{Safety Assessment}

The existing project site and structures were inspected by by TAMS engineering, geological and environmental personnel. Additionally, all prior safety inspection reports, prepared in accordance with FERC order 315, were reviewed.

It has been concluded by TAMS that the existing structures have been well maintained and with continued maintenance of a similar standard will serve adequately for the life of the new structure. It has also been concluded that the proposed new structure will not create any unsafe conditions with potential to cause loss of life or economic loss. 


\section{Land Use}

The proposed project is located in the riverbed of the Saco River inside the present project boundaries as shown on Figure 2 and adjacent to Factory Island. This land is currently owned by CMP. CMP currently have arrangements with the Tanning Company for access to the existing West Channel Dam and will negotiate for additional access for operation and maintenance of the powerhouse and for transmission line routes.

\section{Regulatory Reguirements}

As the proposed project constitutes a major revision to the existing project an application will have to be filled with the Federal Energy Regulatory Commission (FERC) for a relicensing of project No. 2528. Because. the project capability exceeds 2000 horsepower the application will be considered as a major project. Should pending legislation authorizing a revision to the regulations be implemented prior to filling this application the designation of "Major Project" could be affected.

The Saco River is designated a navigable waterway by the U.S. Corps of Engineers, thus, the project will require that a dredging and fill permit be obtained from then. Additional Federal Regulations require consultation with the Enviromental Protection Agency.

Construction of all hydroelectric projects requires approval, coordination or cooperation from State and local authorities. A list of authorities previously consulted on similar projects in the state of Maine follows:

City of Saco

City of Biddeford

Public Utilities Commission

Board of Envirommental Protection

Department of Inland Fisheries and Game.

Department of Marine Resources 


\section{E. ENERGY PRODUCTION}

\section{Capacity Addition}

At design head and best turbine efficiency the capacity addition in the new power plant will be $6,240 \mathrm{~kW}$. At design head and full turbine power the capacity will rise to $7,500 \mathrm{~kW}$.

\section{Proposed Operation}

Essentially the new plant will be operated in a manner similar to the existing plant. For high flows the new and the old plants will be operated so as to utilize as much of the available water as possible. During times of moderate and low flows operation will be scheduled to obtain the maximum energy possible based on considering available head, releases from the Skelton Plant and the available daily storage at Bradbury and Springs Dams. Essentially, this will be a part day basis at best efficiency unless otherwise dictated by system load demand. In this latter mode some constraints will be necessary if more than one unit is quickly brought on line as only the gate at Bradbury dam is remotely operated from the control room. The three gates in Springs dam are operated at the gatehouse. The discharge capability of the Bradbury gate is just sufficient to operate either the existing or the proposed plant at full load. After some operational experience has been gained with the new units it may be found desirable to revise the Springs Dam gates to provide for remote operating facilities in the control room so as to allow added flexibility for short period high capacity operation in the low flow period.

\section{Energy Generation}

The energy which could be generated by the project was estimated using a computer program specifically prepared for this purpose and based on 60 years of historical flow records for the Saco River. No adjustment was made for upstream storage because the volume is small and would effect the energy only on a daily basis. Allowances were made for use of this daily storage. 
Only river flow in excess of that capable of being used by the existing plant was considered in calculating the energy available from the new plant. In addition, 300 cfs was deducted from stream flows to allow for prior water rights, purchased process water, fish ladder releases and gate and flashboard leakage. No allowance was made for scheduled outages as it is considered that these will be scheduled in the low flow period when the remaining two units can recover all available energy. No allowance was made for unscheduled outages, nor for transmission and distribution losses.

This analysis gave the following results:

\begin{tabular}{lr}
\multicolumn{1}{c}{ Period } & Average E \\
\cline { 2 - 2 } & MWhrs \\
Annual & 15,910 \\
January & 680 \\
February & 560 \\
March & 1,610 \\
Apr il & 4,790 \\
May & 4,070 \\
June & 1,190 \\
July & 230 \\
August & 100 \\
September & 150 \\
October & 290 \\
November & 1,020 \\
December & 1,120
\end{tabular}

It should be noted that the above energy values are averages and in some cases wide variations occur between the wettest and driest year of record. Table I shows energy generation in chronological order of the 60 years of historical flow records while Table 2 shows energy generation ranked in order from driest to wettest period. 
MONTHLY AND ANNUAL GENERATION

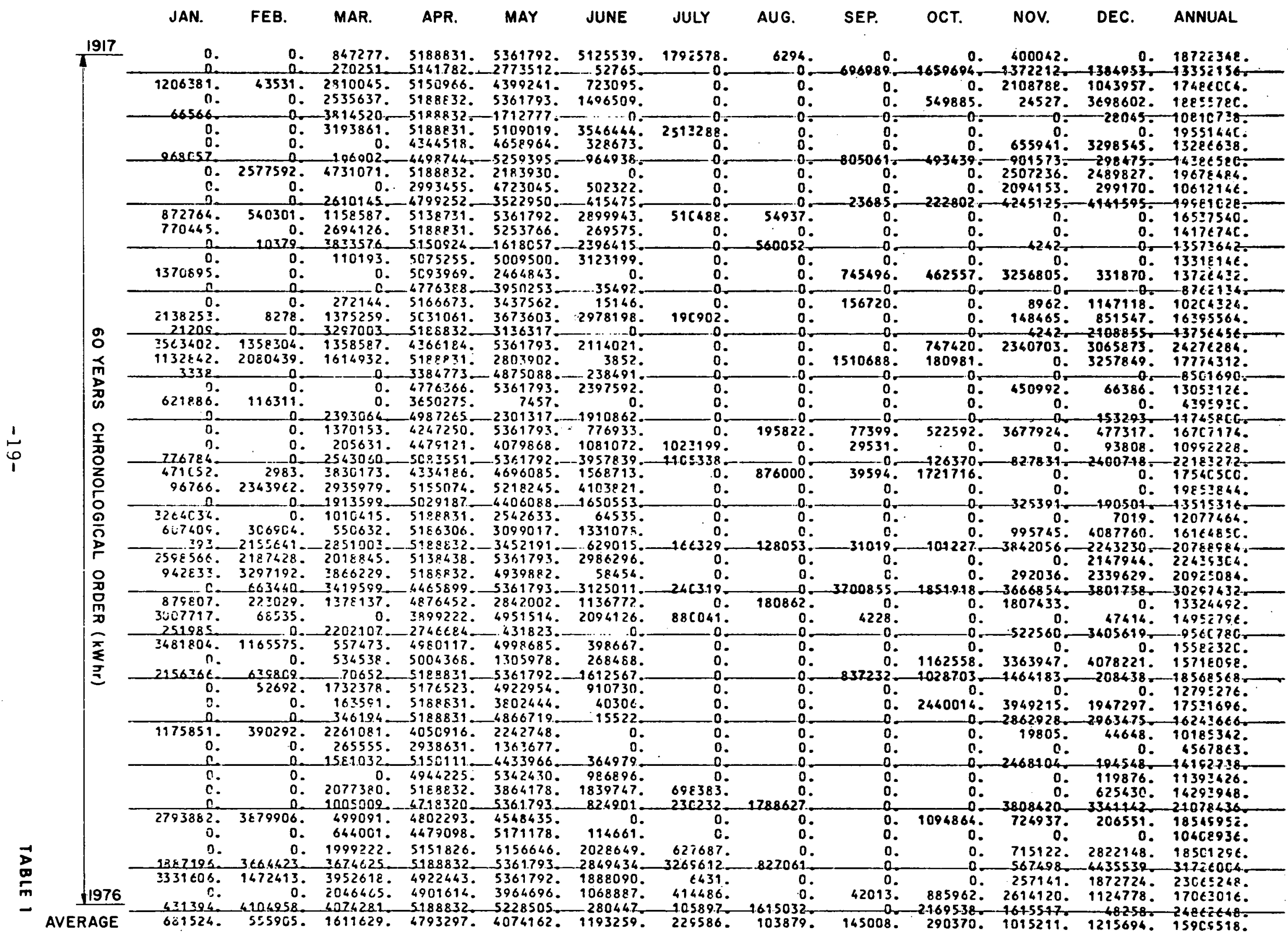




\section{SORTED MONTHLY AND ANNUAL GENERATION}

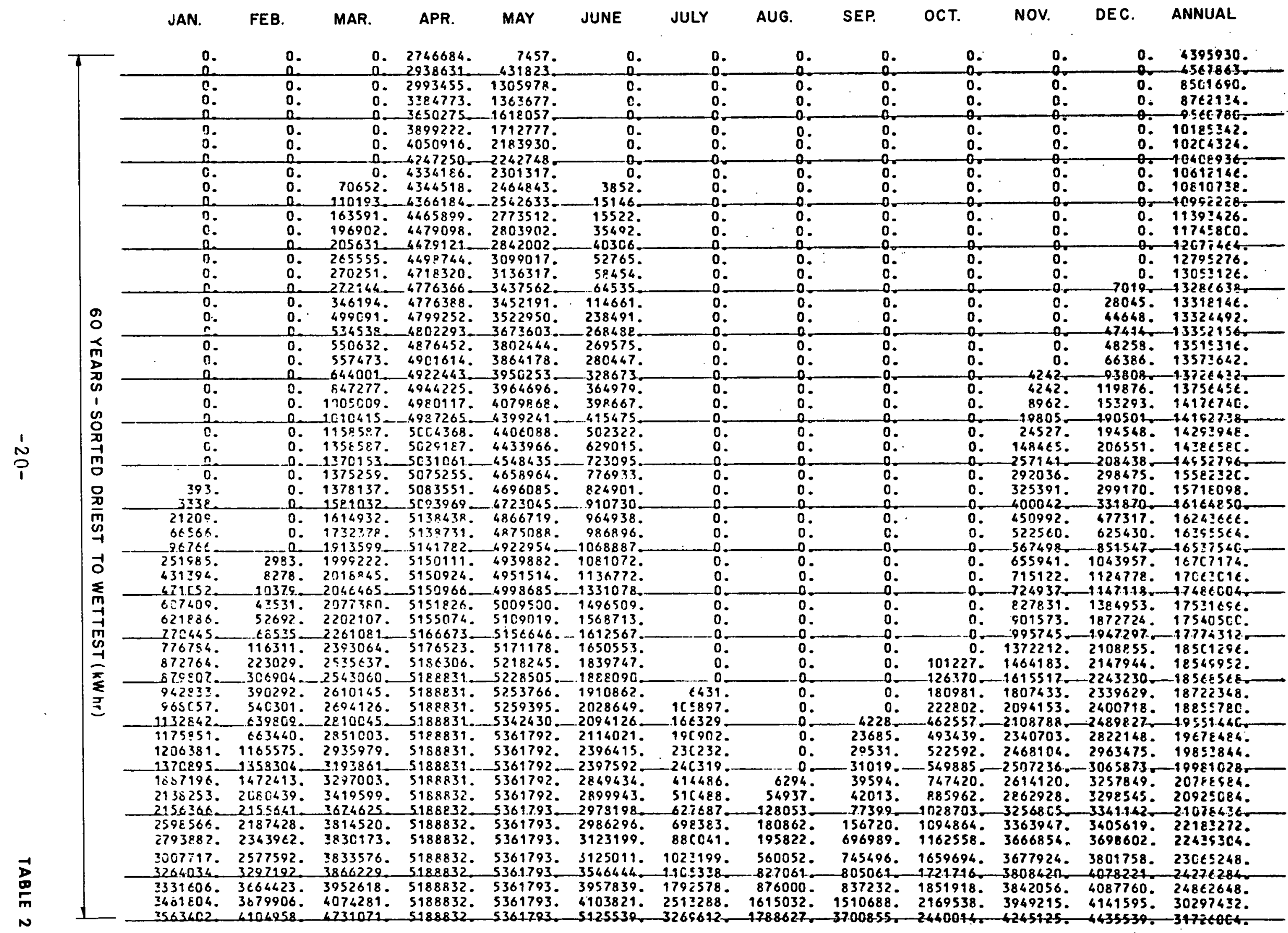




\section{F. PROJECT COSTS}

\section{Cost of Construction}

The estimated Gross Plant Investment, at early 1979 prices, is $\$ 5,230,000$. This estimate is presented as Table 3 . It is based on the recommended project layout considering the construction schedule described in section D III.

The costs are based on quantity take offs as developed from the plan for each project feature. Appropriate unit prices have been applied to obtain the cost estimate. Unit prices for civil works construction are generally based on bid prices obtained for similar types of construction adjusted for escalation.

Manufacturers supplied the cost of electrical and mechanical equipment. Lump sum allowances have been included for the delivery. and installation of appropriate items. The cost of miscellaneous power plant equipment includes an allowance for items such as draft tube bulkhead, storm louvers and exhaust fan, access stairs, trashracks and similar equipment.

The following percentages were added to the direct construction cost to allow for omissions and contingencies:

$\begin{array}{ll}\text { Electrical and Mechanical Equipment } & 10 \% \\ \text { Civil Works } & 20 \%\end{array}$

Engineering costs were estimated to be $13 \%$ of the above total.

\section{Cost of Operation and Maintenance.}

Operation of the new power plant will be performed remotely from the present Cataract Power Plant control room which is staffed full time. Routine day to day surveillance and dam operation is also presently performed by the existing Cataract staff. It is anticipated that the new structures 
can be fitted into their present schedule. Thus, no increase in cost for operation and routine day to day surveillance will occur due to more efficient use of the existing staff.

Incremental cost for items of materials such as oil, grease, spare and replacement parts and overhaul maintenance, and associated labor will occur. Based on experience with other operating plants in the system the present day average annual cost of these materials and labor is estimated to be $\$ 40,000$. This cost for these services and materials will of course escalate annually throughout the life of the project in accordance with the area trend. 
Table 3

CATARACT POWER PLANT EXPANSION

SUMMARY OF PRELIMINARY COST ESTIMATE

FERC

Account

I tems

Estimated Cost (\$)

330

LAND AND LAND RIGHTS

50,000

331

POWER PLANT AND STRUCTURES

Powerhouse

670,000

332

RESERVOIRS, DAMS AND WATERWAYS

Open Flume

370,000

Tailrace Channel

140,000

Breech Existing Dam

20,000

333

TURBINES AND GENERATORS

Turbine-Generator Package

$2,060,000$

334

ACCESSORY ELECTRICAL EQUIPMENT

Generation Controls and Protective Switchgear

80,000

Step up Transformer

Miscellaneous

High Voltage Line Connections

65,000

35,000

20,000

335

MISCELLANEOUS POWER PLANT EQUIPMENT

20,000

DIRECT CONSTRUCTION COST

$3,530,000$

OMISSIONS AND CONTINGENCIES

500,000

SUB-TOTAL

$4,030,000$

ENGINEERING COST.

520,000

LEGAL-ENVIRONMENTAL-ADMINISTRATIVE AND

OVERHEADS

250,000

SUB-TOTAL SPECIFIC CONSTRUCTION COST

$4,800,000$

ALLOWANCE FOR FUNDS DURING CONSTRUCTION

430,000

GROSS PLANT INVESTMENT

$5,230,000$ 


\section{G. ECONOMIC ANALYSIS}

The various expansion alternatives at Cataract Station were compared with peaking fossil costs of the same capacity and annual energy. Total annual costs were calculated for the various hydro/fossil comparisons over the life of the hydro facilities.

Since an addition at Cataract will be primarily a peaking unit, operating for a limited number of annual hours, the fossil alternative costs selected for comparison were those associated with a $50 \mathrm{MW}$ gas turbine. The energy that would be produced by the Cataract addition, however, would replace fossil fueled generation at various times of the year. For this reason an average current fossil fuel cost of $24 \mathrm{mills} / \mathrm{kW}$ hr was assumed and escalated at 68 per year over the life of the hydro plant, resulting in a levelized fuel price of 52 mills.

Annual fixed charges, comprised of depreciation, interest, equity return, taxes, insurance, operation and maintenance, and administrative expenses were determined to be approximately $20 \%$ of the gross plant investment for both the hydro and fossil alternatives.

The results of this comparison are shown in Table 4.

Note that the adjustable bladed machines offer greater annual savings than the fixed bladed options. This is due in large part to being able to pass more water through the turbine during periods of excess flow.

The $3000 \mathrm{~mm}$ and $2500 \mathrm{~mm}$ machine sizes show about equal annual savings $(\$ 125,000$ and $\$ 129,000$ respectively). The $\$ 4000 /$ year difference would correspond to an investment difference of $\$ 20,000$, which is less than $1 \%$ of gross plant investment, well within the estimating contingency range. 'Ihe $2500 \mathrm{~mm}$ machine does show lower annual energy cost estimates (65.7 mills/ kWh vs. $69.8 \mathrm{mills} / \mathrm{kWh})$.

No allowance has been made in the estimates of Table 3 for construction of the anadromous fishway. Current estimates indicate that such a 
fishway could cost about a half million dollars (or an annual cost of $\$ 100,000)$. Inclusion of a fishway in the project costs almost eliminates the economic benefits associated with the Cataract expansion (Table 4, Line 14$)$.

Another point influencing economic viability is the expiration date of the current FERC license, December 31, 1987. Based on current CMP experience with federal and state licensing procedures, the earliest possible in-service date for the additional Cataract units would be the Fall of 1984. This would allow only slightly more than three years of operation under the current license. The expansion of Cataract cannot pe justified over such a short time frame. 
TABLE 4

CATARACT HYDROELECTRIC DEVELOPMENT

EXPANSION STUDY

ECONOMIC COMPARISON

ADJUSTABLE BLADES

1. Turbine Size (mm)

2. Rated Capacity ( $\mathrm{kW})$

3. Maximum Capacity (kW)

4. Average Annual Energy (Mwhr)

HYDRO

5. Gross Plant Investment $(\$, 0000)$

6. Investment/Installed $\mathrm{kW}$ (\$)

7. Annual Cost $(\$, 000)$

8. Annual Energy Cost (Mills/kWhr)

6,758

804

6,104

836

1,352

1,221

69.8

69.1

5,230

838

4,524

913

6,540 778

FIXED BLADES

\begin{tabular}{rrr}
\multicolumn{4}{c}{ FIXED BLADES } \\
\hline 3,000 & 2,750 & 2,500 \\
8,400 & 7,300 & 6,240 \\
8,400 & 7,300 & 6,240 \\
17,090 & 15,520 & 13,850
\end{tabular}

\section{FOSSIL ALTERNATIVE}

9. Gross Plant Investment

10. Annual Fixed Cost

$(\$, 000)$

勿

11. Annual Fuel cost

12. Total Annual Cost

$(\$, 000)$

$(\$, 000)$

13. Annual Savings with Hydro $(\$, 000)$

14. Annual Savings with Hydro $(\$, 000)$ (including fishway)
2,352

\begin{tabular}{r}
470 \\
1,007 \\
\hline 1,477 \\
125 \\
25
\end{tabular}

\begin{tabular}{r}
2,037 \\
407 \\
919 \\
\hline 1,326 \\
105 \\
5
\end{tabular}

\begin{tabular}{r}
1,740 \\
348 \\
827 \\
\hline 1,175 \\
129 \\
29
\end{tabular}
1,380
276

$1,949 \quad 1,696 \quad 1,448$

$390 \quad 339 \quad 290$

$\frac{890}{280} \quad \frac{807}{1,146} \quad \frac{719}{1,009}$

(28) (20) 6

(128) (120)

(94) 


\section{H. ENVIRONMENTAL ASSESSMENT}

\section{Description of Existing Environment}

The proposed project would develop the hydroelectric potential of the West Channel of the Saco River which divides the Cities of Saco and Biddeford, York County, Maine. The preferred development, which would utilize the existing Upper York Dam (also called West Channel Dam) at its présent elevation, is described in section $C$ of this report. The site is located above the head of tide, approximately three miles upstream from the Atlantic Ocean, within the state's coastal zone. Resource summaries for this zone have recently been prepared by the Maine State Planning Office (MSPO, 1977).

The Saco River, which drains a 1,703 square mile area, originates in the White Mountains of New Hampshire and flows southeasterly for 125 miles to the head of tide at Saco, Maine. The Department of Environmental Protection (DEP) indicates that about half ( 827 square miles) of the drainage basin is located in Maine with an average slope of $4.5 \mathrm{feet} / \mathrm{mile}$ (DEP, 1976). There are a total of eleven dams located on the main stem of the Saco between Saco and Fryeburg, Maine (DeRoche, "1956)."

Along much of the length of the river above the study site, the saco River Corridor Commission has implemented land use and development controls (extending up to 1000 feet on either side of the watercourse) which have helped to minimize the pollutants entering the river. The saco is classified as having Class " $C$ " water fram Thatcher Creek (about .5 milès upstream of the project site), to tidewater (DEP, 1976). Class C water is satisfactory for recreational boating and fishing, for $f i s h$ and wildifife habitat, and for other uses except potable water supplies and water contact recreation, unless such waters are adequately treated.

The section of river below the project site is brackish, under tidal influence, and is classified "SC" (DEP, 1976). Class SC water is satisfactory for recreational boating, fishing, and other similar uses except 
primary water contact. It is also suitable for fish and wildlife habitat and for industrial cooling and process uses. High fecal coliform bacteria levels in the waters below the site have forced the closing of the shores, flats and tributaries (including Biddeford Pool) to shellfish fishing since April, 1972 (DEP, 1976). The decrease in water quality below the SacoBiddeford area is due in part to discharges from the Biddeford waste water treatment fäcility, as well as a primary treatment facility on Eactory Island (DEP, 1976).

A warm water fishery exists from the project upstream about 30 miles to Steep Falls with the primary game fish being bass and pickerel (De Roche, 1968). Summer water temperatures in this section of the Saco River are generally above $78^{\circ} \mathrm{F}$ (De Roche, 1956) and thus the section is not managed for trout. Although there is a fishway in the Upper York Dam; salmon and other anadramous fish runs have not been observed for many decades (De Roche, 1968). The potential for re-establishment of Atlantic Salmon exists however, since the Maine Department of Marine Resources and Atlantic Sea-run. Salmon Comission stocked salmon smolts in the Saco as recently as 1975 .

Fish and willdife maps published as part of the Maine Coastal Inventory indicate the presence of striped bass as well as two concentrated fisheries in the Saco River estuary, the latter being specific locations where anadromous fish species are harvested on a commercial scale (MSPO, 1977). The American eel, which lives in fresh water and runs to the sea to spawn, is shown on the map as inhabiting the Saco River from the Cataract Dam upstream for about 7.5 miles.

The terrestrial enviroment in and around the project site is severly limited by the industrial use of the island. The powerhouse area is largely covered by paved roadways and curbing with sparce, poorly formed woody and herbaceous growth competing for the small amount of available growing space. Its habitat value is very low.

The Maine Coastal Inventory indicates the presence of wetlands ten acres or larger at several locations along the shores of the Saco River 
estuary, its tributaries and Biddeford Pool. Portions of eight wetlands have been ident if ied as being important to waterfowl (MSPO, 1977).

There is no apparent public use of the land and water surrounding Factory Island for recreation. The nomal full pool created by the existing Cataract Project is about 14 acres and extends upstream only 0.3 miles to Springs and Bradbury Dams (Technical Proposal, 1978). Poor access caused by the close proximity of buildings to the water's edge, steep rocky banks, and strong currents limit public use immediately upstream. A Yacht Club, marina, and an excursion boat line are located in the tidal estuary a short distance downstream. Sport fishing for striped bass and blue fish is reported to occur in the Saco River estuary at various times of the year.

The combined Saco/Biddeford population for 1978 is about 33,000 and is expected to increase to 35,100 by 1985 (Mr. David Katon, Personal. Communication). Factory Island, a part of the City of Saco, is located between the downtown areas of Saco and Biddeford. Saco has zoned the project site as I-l (Industrial District) a designation which provides "for inaustries and their expansion" (Zoning Ordinance, 1977).

The City of Biddeford recently completed a three month study to detenmine how to improve the downtown area and reverse a ten year trend of lost jobs and taxes by implementing a development plan. The proposed plan includes street improvement, expanded parking, and a loan pool to increase utilization of factory buildings located along the Saco River opposite the project site (Mr. David Katon, Personal Communication). It has been reported that the Saco River Corridor Commission has zoned this stretch of the Saco River as a General Development District. The development of hydro power is consistent with this designation.

The Saco Tannery, the only industry located on Factory Island is entitled to a portion of the stream flow (275 cfs for 18 hours/day) for use in the tanning process and to produce electricity. The tannery withdraws water throughout the year except for a two week period in the summer when the factory shuts down. The intake is located just upstream of the eastern abutment of the Upper York Dam. 
Vehicular traffic to the project site must pass through the tannery on narrow roadways with little distance between the buildings, but the road pavement though the site itself is free from obstruction by buildings, as well as removed from major traffic lanes.

The general appearance of Factory Island and the City of Biddeford from the project site is typical of an urban industrial complex built around 1900. The red brick factory buildings are long and massive consisting of several stories. The west Channel below Upper York Dam consists of rock outcroppings steeply sloping toward the sea across which the water winds its way through the many fissures and channels which criss-cross the bedrock. The remains of Lower York Dam (now abandoned), which lie generally across the direction of flow have been breached in several locations. The west section and its abutment, on the Biddeford side has been completely washed away exposing part of the building foundation.

Although there has been activity in this area by Indians and the early settlers, repeated fires and subsequent development have had a substantial impact on the area. The Maine Historic Preservation Commission indicates that there are no structures or sites of historic or archaeological significance (Shettleworth, 1978). Additionally, the project involves only minimal excavation since most of the development will occur away from the existing shoreline.

\section{Effects of Construction and Operation}

A description of the project features and a general discussion of the construction procedures appears in Section $D$.

Construction of the project will have very little affect on the turbidity of the water in the Saco River. Most of the excavation will be in rock and natural contours will protect the work from unwanted inundation. A small cofferdam may be required for trailrace construction and to protect rock excavation and other work during the two week period when the 
pool above Springs and Bradbury Dams will be lowered, however, little turbidity should result. The contractor will be required to implement erosion and sediment control measures as appropriate. Some additional dust, noise and exhaust emissions will occur but will be minimized and conform to state and federal requirements. Such effects should haraly be noticeable, given the highly urban-industrial nature of the project site. Operation of the project would not adversely affect water quality and would have no affect on air quality.

Some increase in congestion within the Saco Tannery will occur because of traffic associated with construction workers and delivery of materials. However, with adequate planning and control, the effects of this should be minimal. The disposal of excavated material not usable on site will generate a limited amount of heavy construction traffic.

A small cofferdam may be required to protect construction of the tailrace. It will be confined to the immediate work area and will likely use the contour of the existing bedrock to prevent water intrusion. Since the area is only inundated during high flow. The cofferdam would not pose an obstruction to fish movement in the Saco River during construction.

Construction would largely take place during low flows and is planned so as not to interfere with the use of water by the Saco Tannery. During the two week period in the summer when the tannery completely shuts down the section of the Upper York Dam at the entrance to the flume will be removed and certain other work accomplished. It may be necessary to lower the 14 acre pool between the Cataract Project and Springs and Bradbury Dams about eight feet for this period using the low level outlet at Cataract Dam. Information concerning the bottom topography of this pool is limited, however, it is likely that there will be little water available to support aquatic life during the drawdown. The aquatic organisms present in this section of the Saco and the effect of the drawdown on them would be addressed as part of subsequent investigations. Since the Saco River Flow will not be interrupted, and the period of drawdown is of limited duration 
during a season not critical to fish spawning or migration, the overall effect on aquatic life should be limited.

Operation of the project would not cause the elevation of the pool above Upper York and Cataract Dam to be different from w̧hät it is at present and would have no effect on the quantity of flow. The fishway in Upper York Dam would not be affected but the presence of a power station on the west channel would provide the flexibility to select which channel to pass the river flow without foregoing the opportunity for power production. This could be of substantial benefit if anadromous fish runs were to be reestablished.

Some of the sparce vegetation growing near the project site might be eliminated during construction but is limited in extent, low in quality, and thus its loss will have little effect on wildiife.

There is no apparent use of the site for recreation. No change in recreational use at the project site in the existing pool upstream to Springs and Bradbury Dams or downstream in the tidal estuary is anticipated either from construction or operation of the project.

Use of this section of the Saco River for power production is consistent with the Saco City zoning ordinance and the Saco River: Corridor Commission. The proposed Biddeford City improvement program would not be adversely affected by the project and the project is compatible with the industrial use in the part of Biddeford generally opposite the project. The Cities of Saco and Biddeford would realize additional income generated by purchase of some materials and supplies during construction and expenditures by construction workers.

Visually the project is compatible with and will somewhat improve the immediate project site. The flow of water which presently passes the fishway and cascades over the irregular bedrock outcrop will continue. High flows however, will be passed through the hydro plant rather than being spilled through the existing tainter gates. 
It is very unlikely that the small amount of grading required for construction will discover artifacts of archeological or historical significance. If any should be encountered appropriate' measures would insure that its importance would be assessed before further disturbance.

\section{Summary}

Based on a comparison of the existing environment with the changes induced by construction it appears that there will be little effect on the natural, cultural, or social environment. Some temporary effects on aquatic life could occur in a 14-acre, 0.3 mile long section of the Saco during the two weeks drawdown. Some minor increase in noise, dust and exhaust emissions associated with construction will occur as will some increase in traffic in the vicinity of the Saco Tannery. None of the construction effects would substantially alter the environment in the long term.

Operation of the project would have no adverse effects on the existing environment and would provide the capability of routing flows through the West Channel without foregoing power production. Although anadromous fish runs above the existing Cataract Project are insignificant at the present time, the interest. in reestablishing use of .the Saco by Atlantic salmon would warrant evaluation of the existing fishway as part of the environmental report if a decision is made to proceed to the next level of investigation.

\section{References}

Department of Environmental Protection. Southern Maine River Basin water Quality Plan, Bureau of water Quality Control. 1976.

DeRoche, Stuart. Saco River Fishery Management, Maine Department of Inland Fisheries and Game. 1956.

DeRoche, Stuart. Maine Rivers: The Saco, Maine Department of Inland Fisheries and Game. 1968.

Katon, David R. Biddeford City Planner who provided information during site reconnaissance, October 19, 1978.

Maine State Planning Office. Maine Coastal Inventory Handbook, Coastal Planning program. 1977. 
Saco City Ordinance. Zoning Ordinance of the City of Saco. 1977.

Technical Proposal. Feasibility Determination of the Low Head Hydroelectric Power Development at Existing Sites, Proposal Number 78-9C, Central Maine Power Company and Tippetts-Abbett-McCarthy-Stratton. 1978.

Shettleworth, Earle G. Letter to Gary G. Boyle from Maine Historic Preservation Commission dated November $27,1978$. 


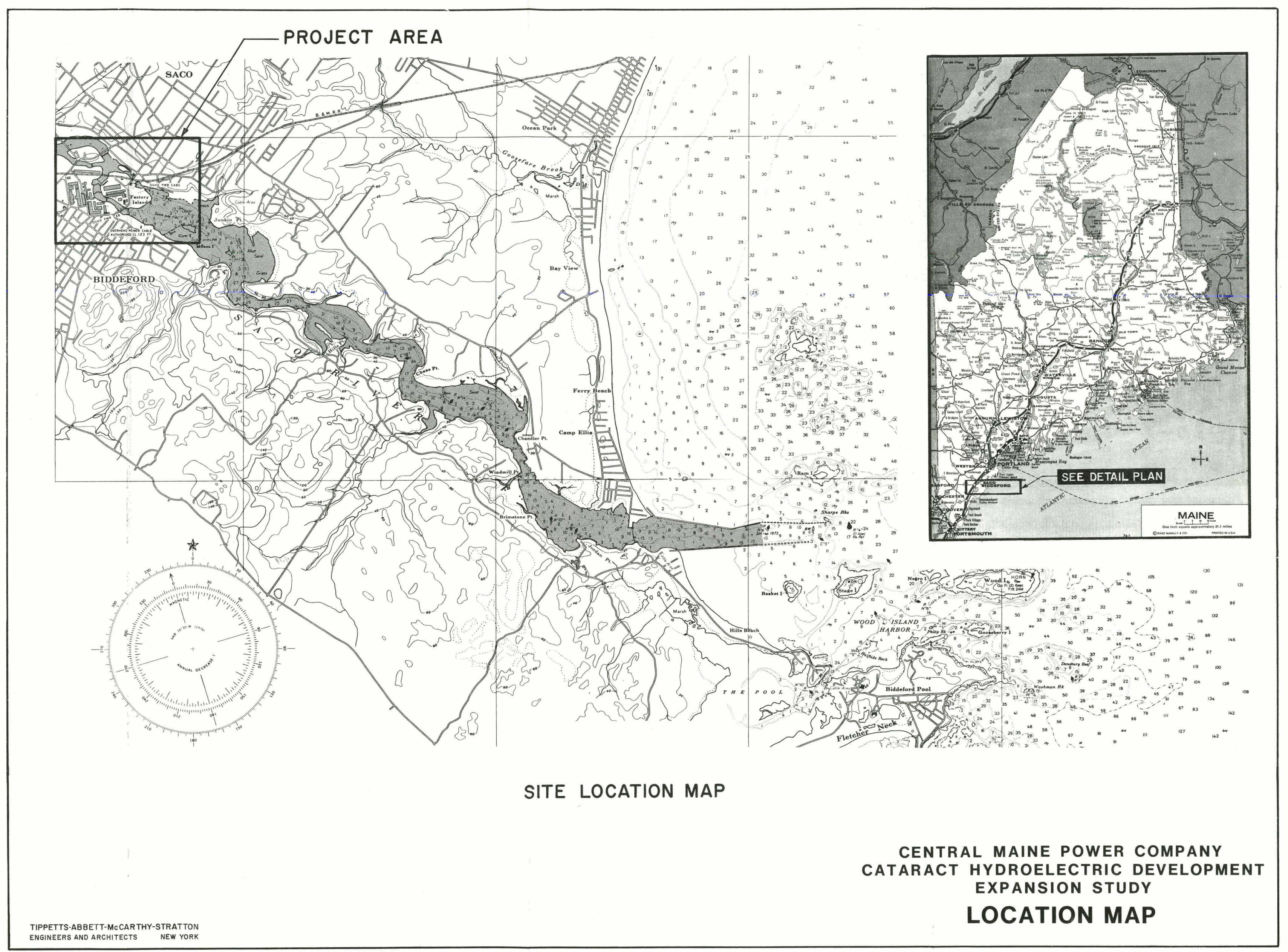




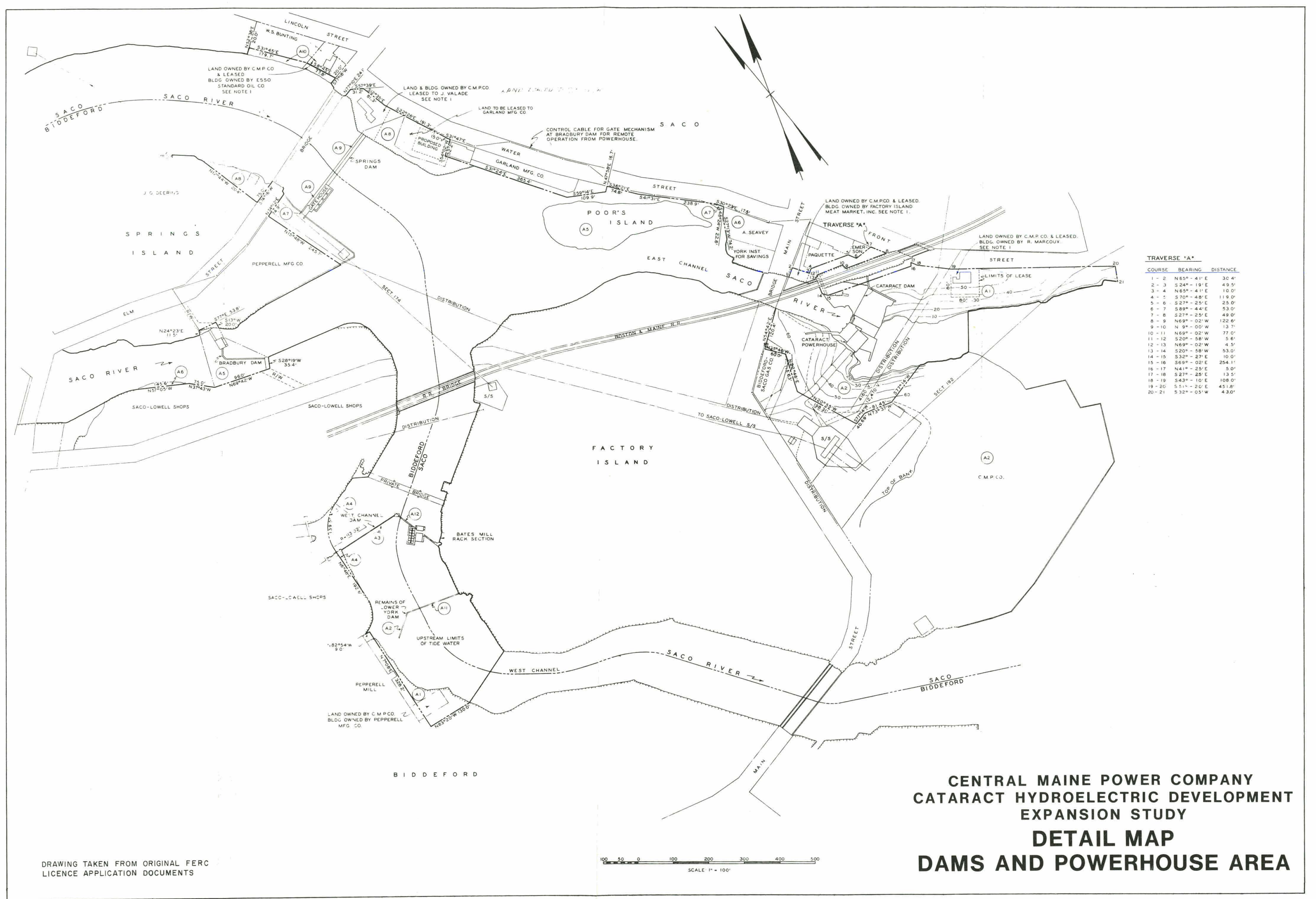




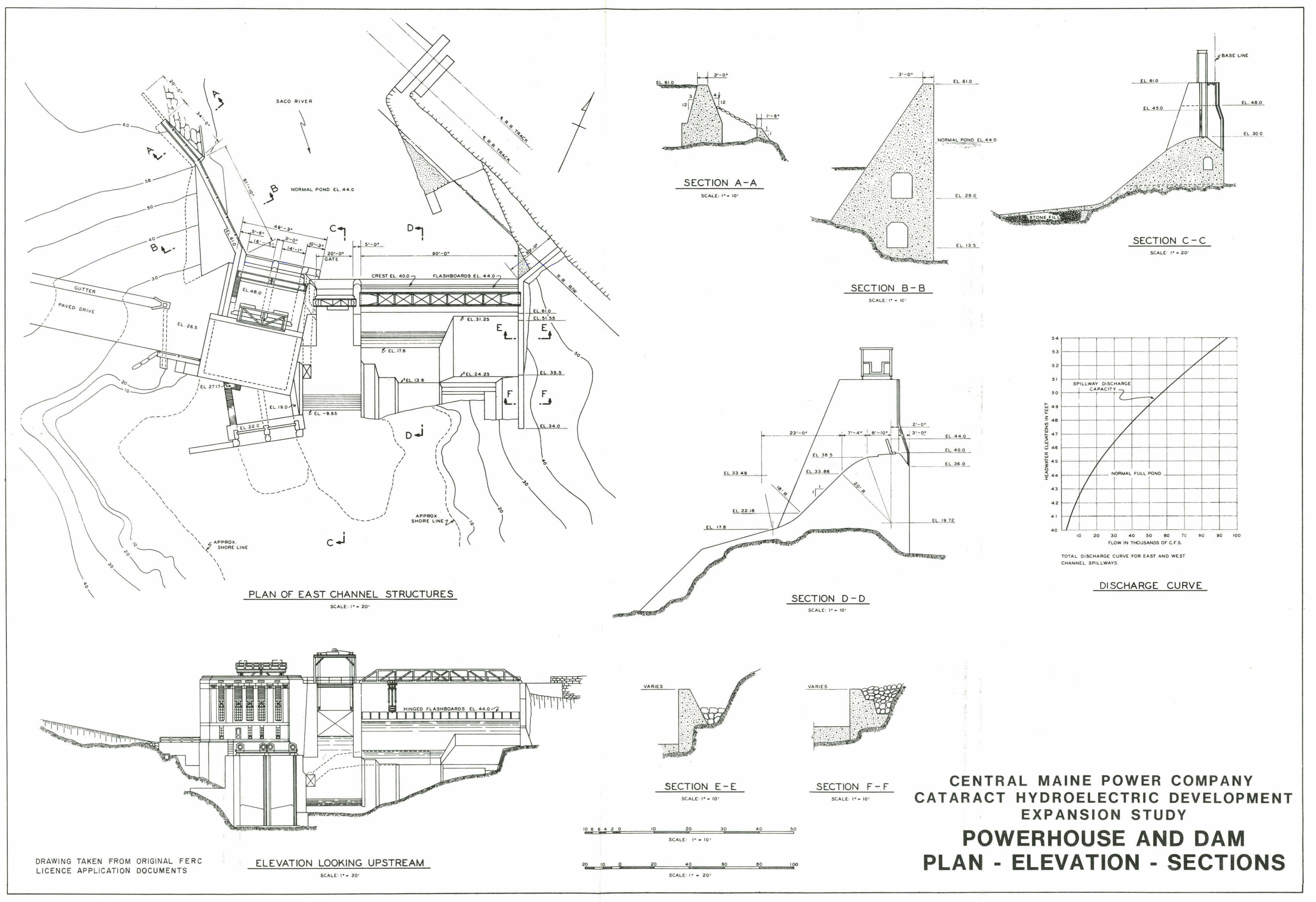



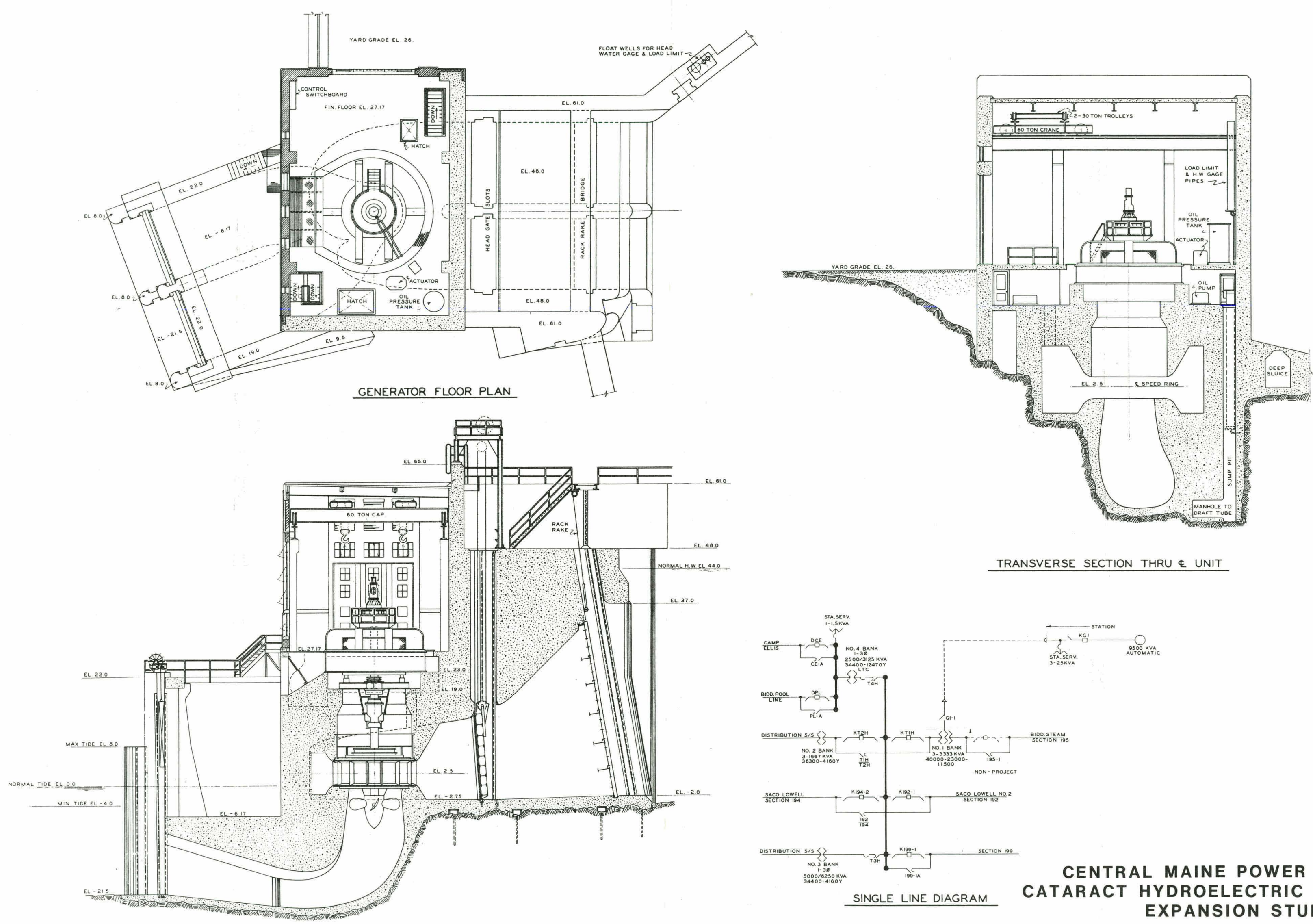

TRANSVERSE SECTION THRU \& UNIT

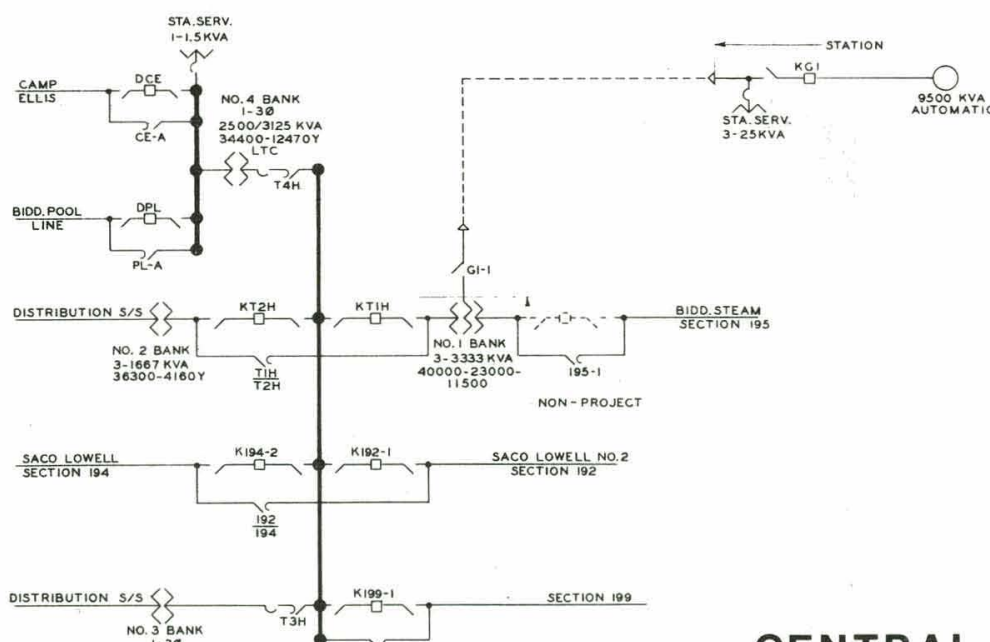

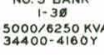

CENTRAL MAINE POWER COMPANY SINGLE LINE DIAGRAM CATARACT HYDROELECTRIC DEVELOPMENT EXPANSION STUDY

POWERHOUSE 


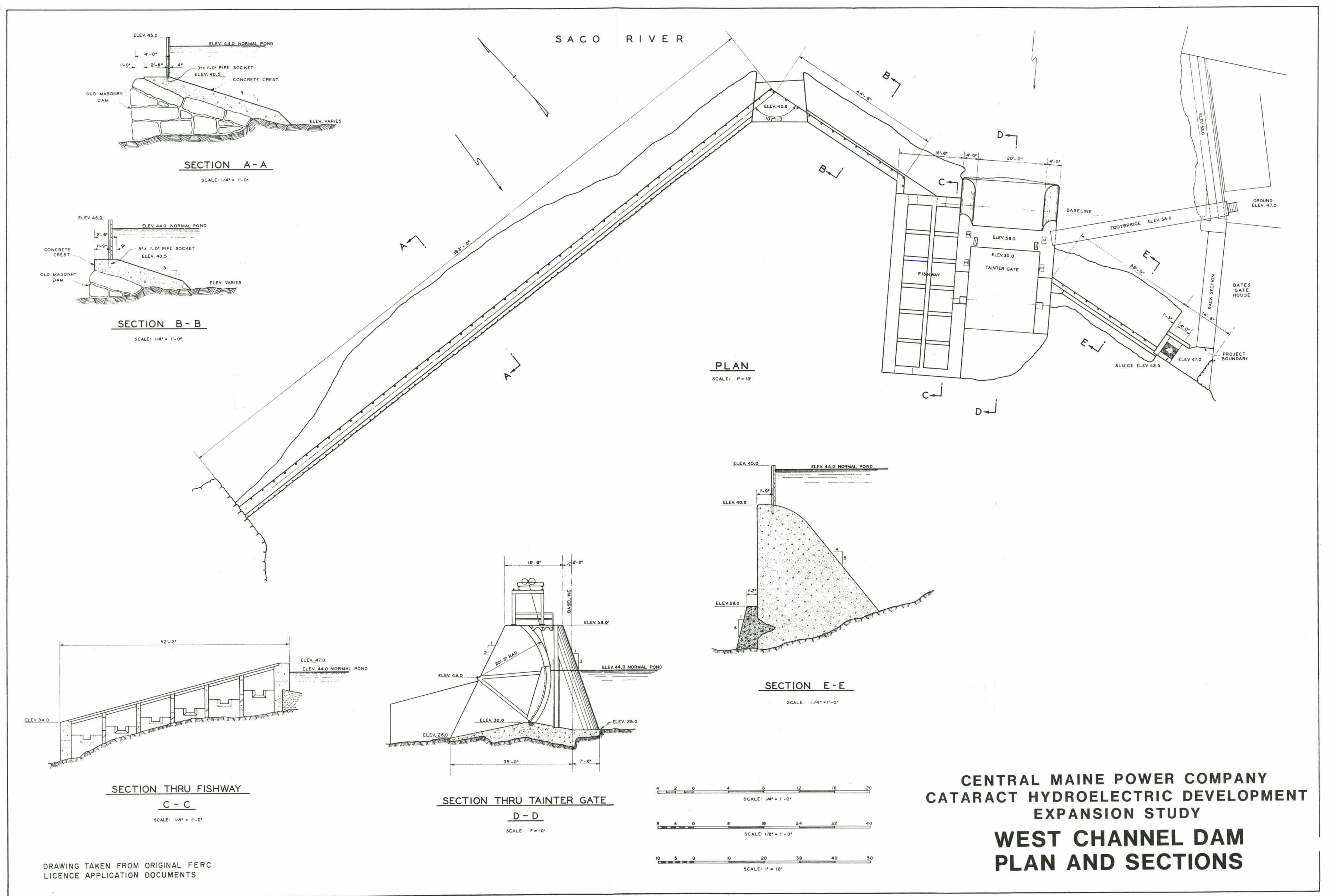




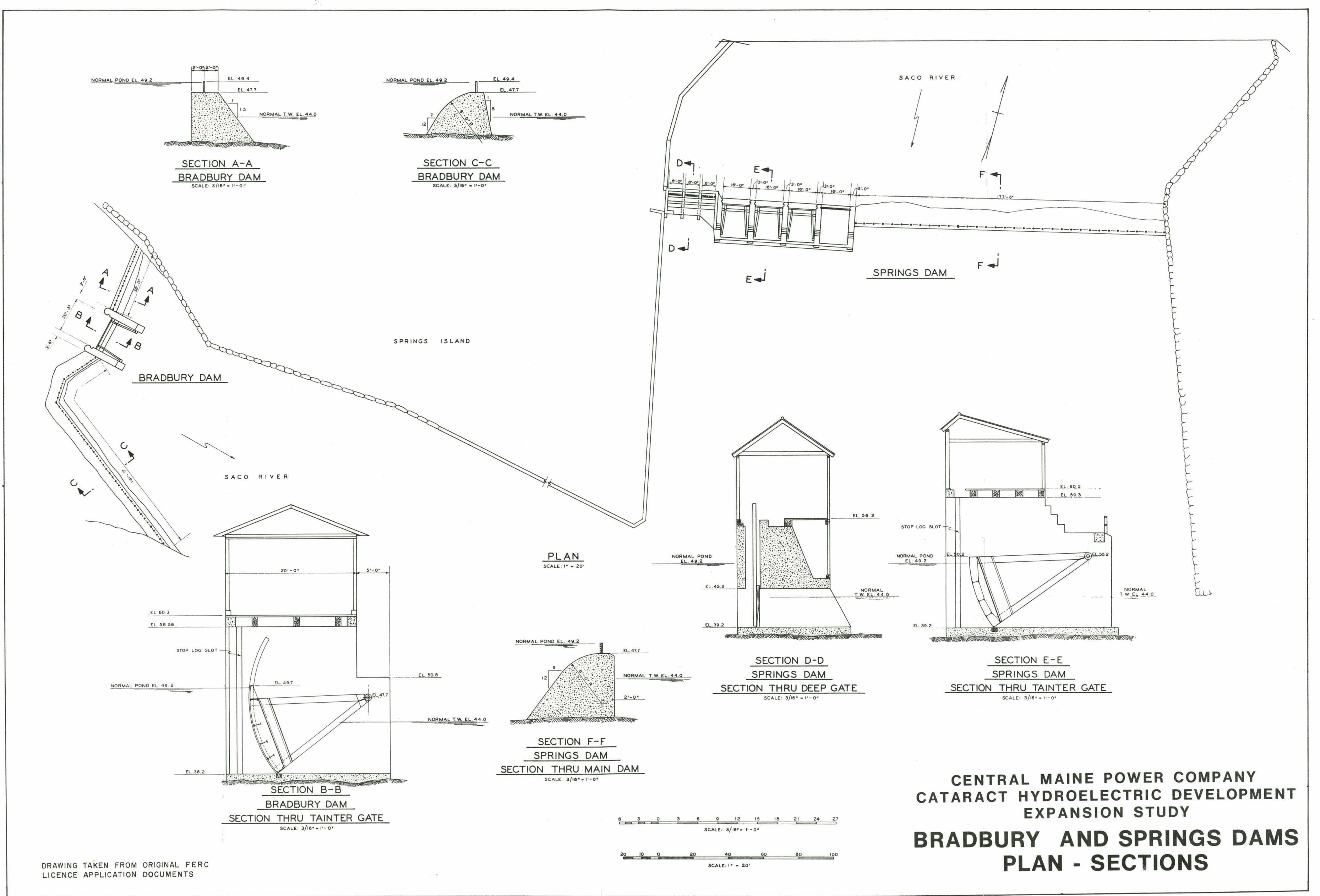




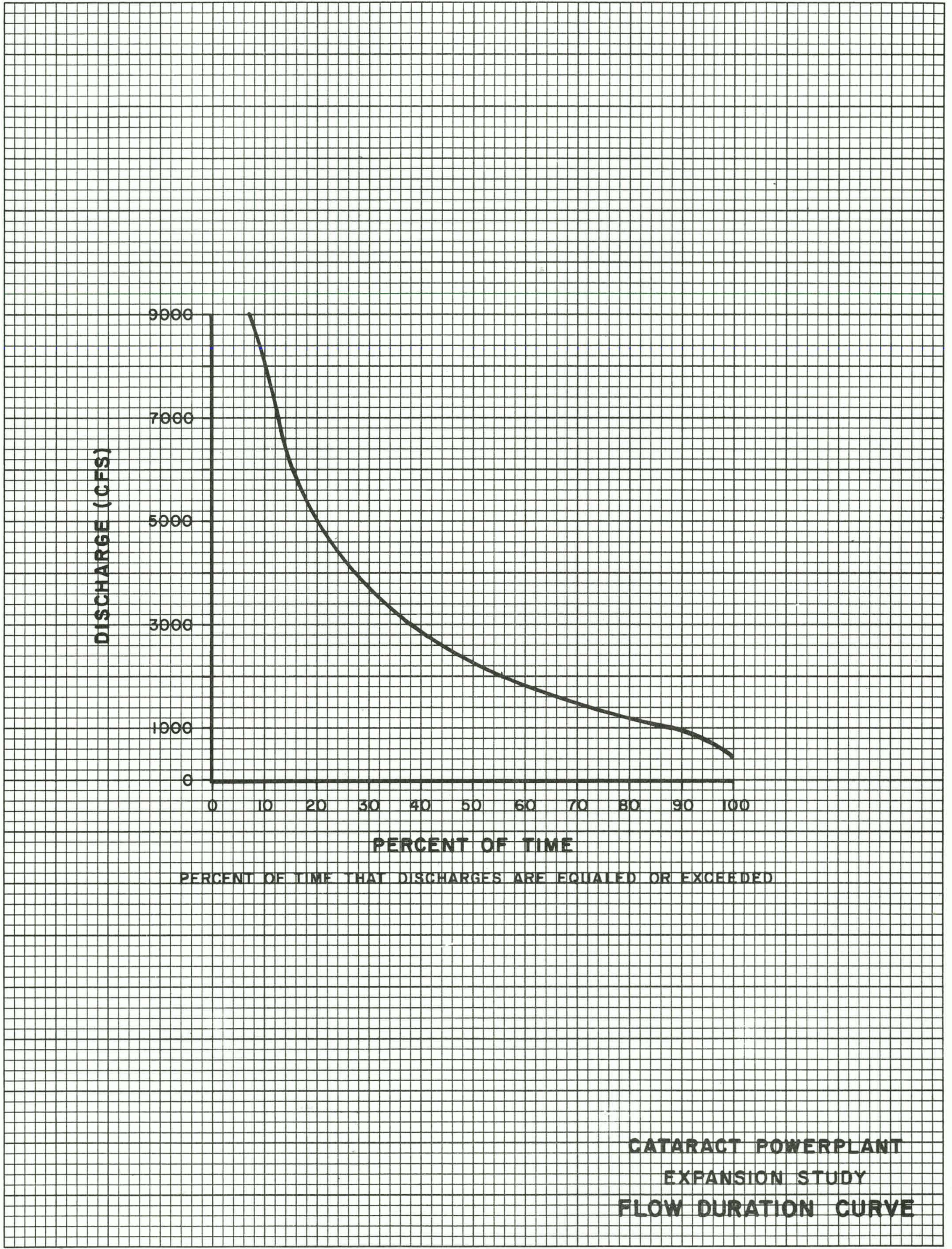




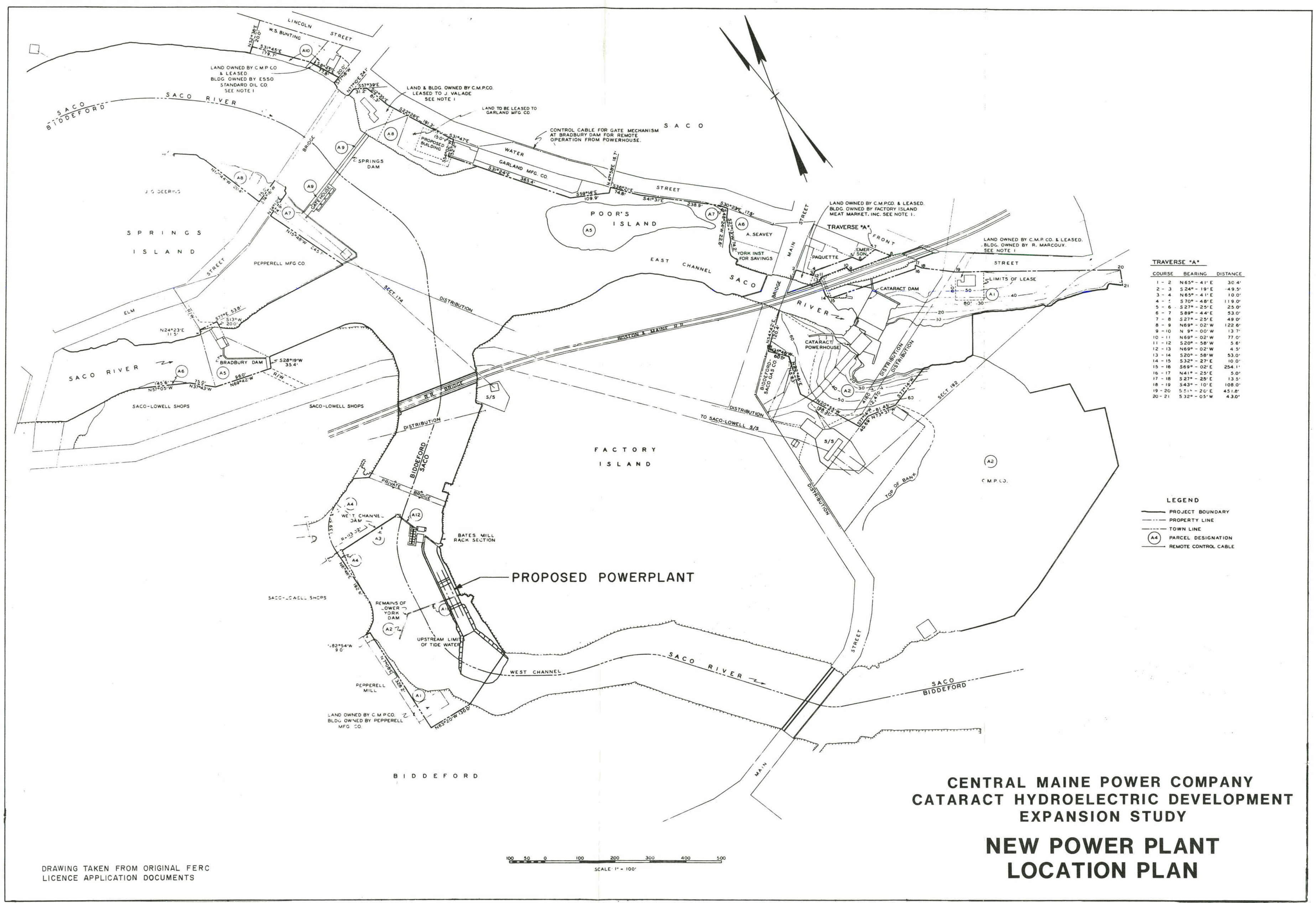




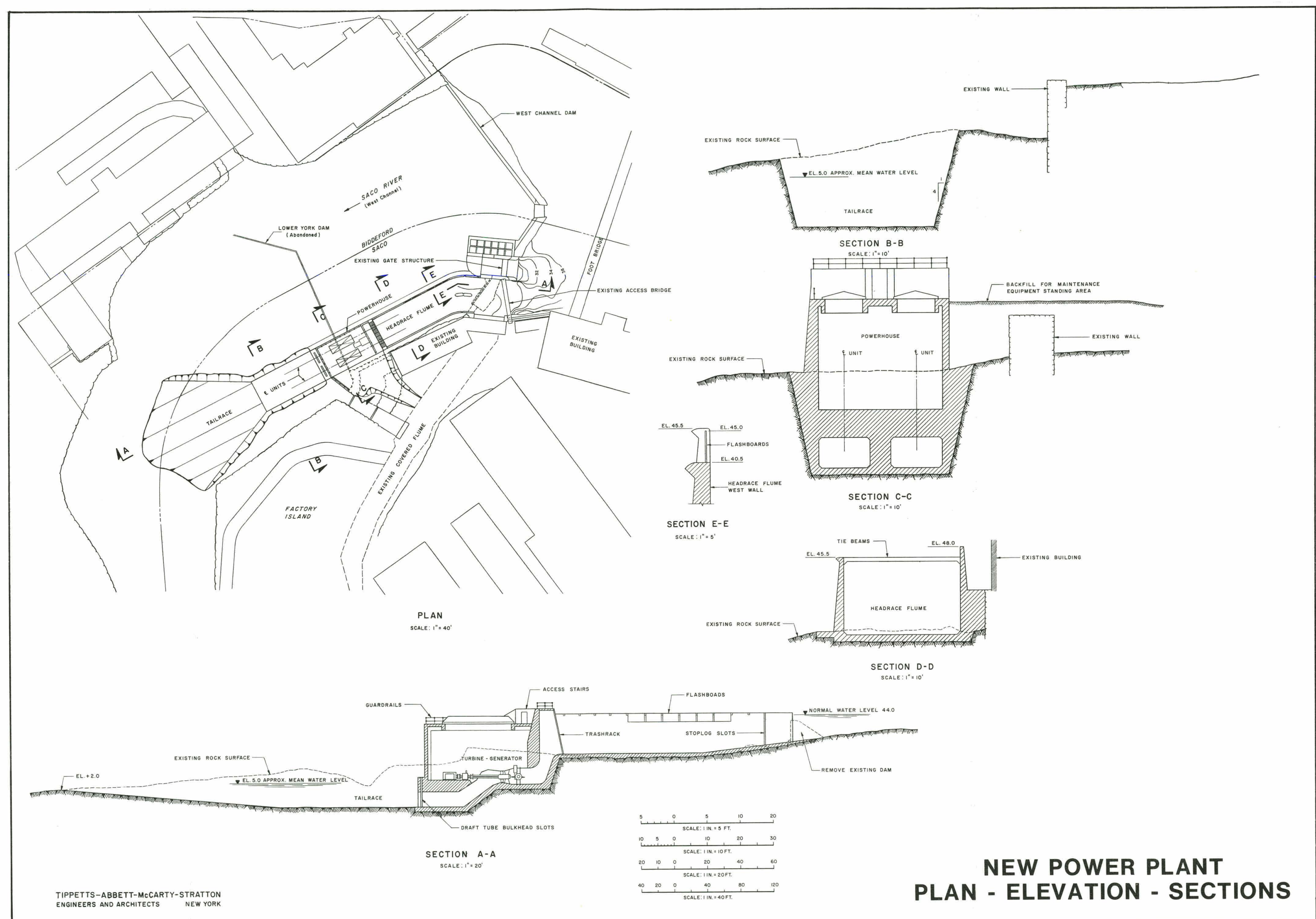


CENTRAL MAINE POWER COMPANY

CATARACT HYDROELECTRIC DEVELOPMENT

EXPANSION STUDY

ELECTRICAL ONE-LINE DIAGRAM

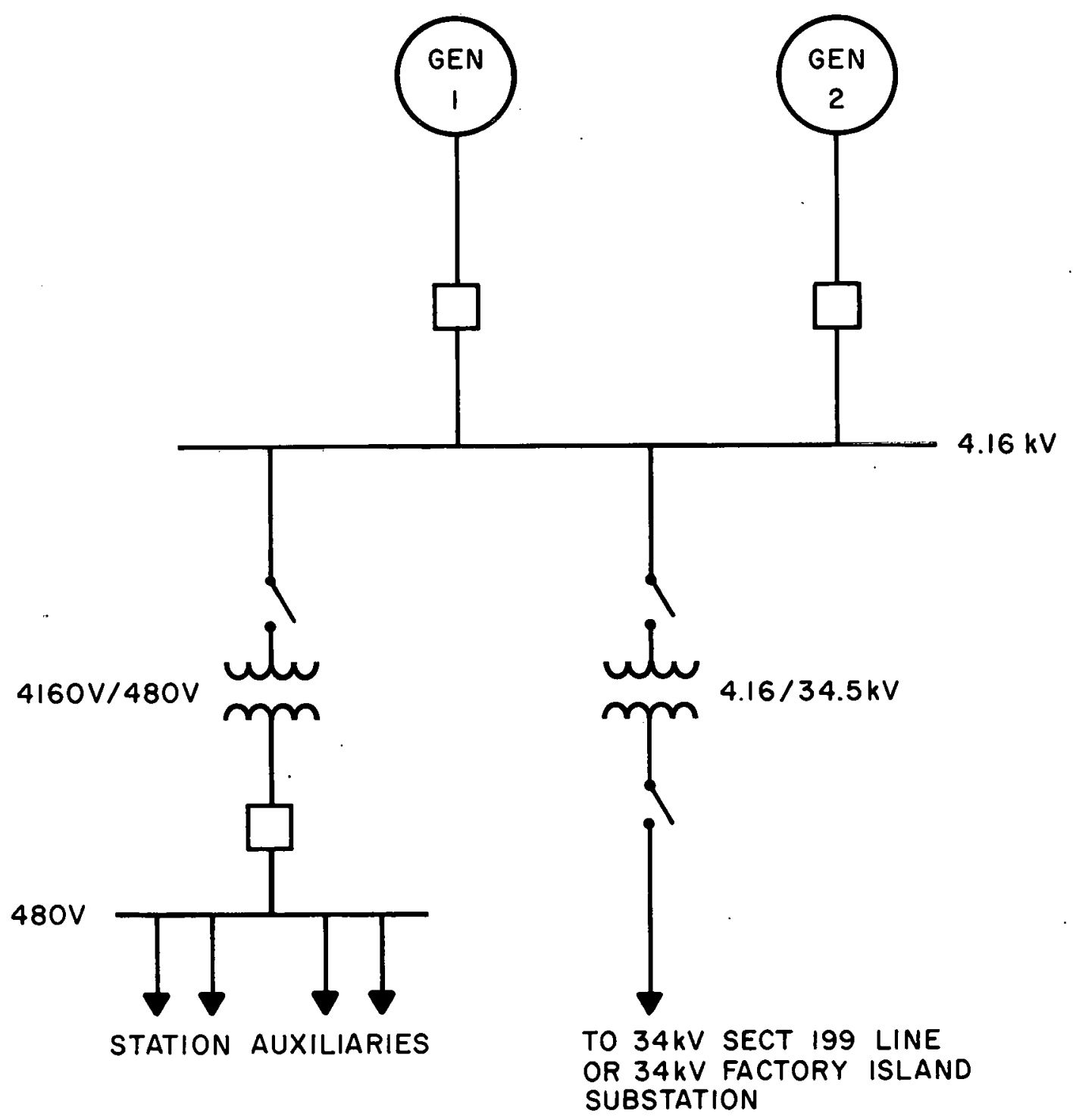




\section{CATARACT HYDROELECTRIC DEVELOPMENT EXPANSION \\ PROJECT DESIGN AND CONSTRUCTION SCHEDULE}

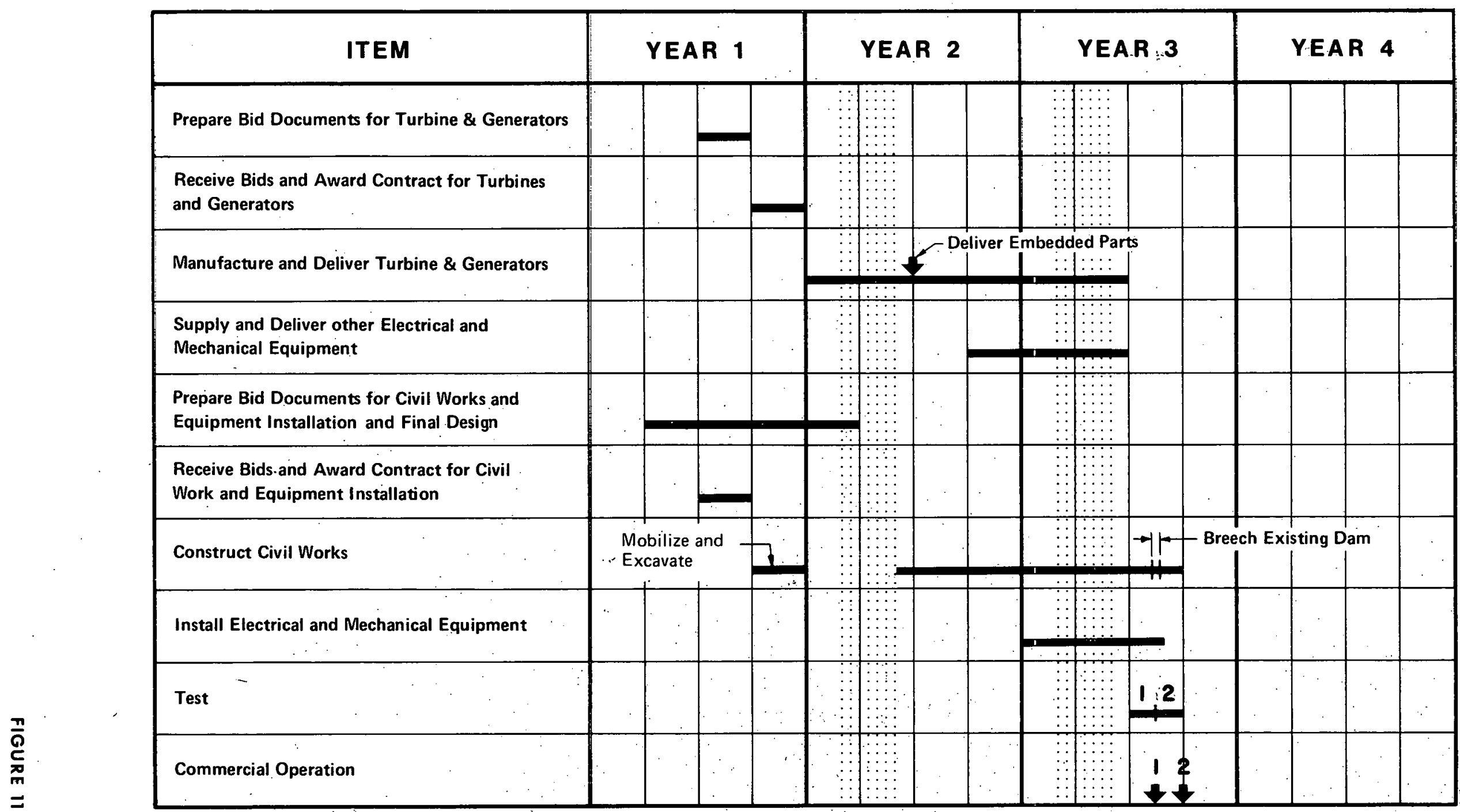

Extreme High River Flow Period 


\section{APPENDIX I}

\section{Alternative Project Studies}

After a preliminary review of the available drawings and data it was concluded that three different basic cases of plant expansion would require study i.e.,

a) Examine the technical feasibility of increasing the power of the existing turbine by installing new rotating parts.

b) Construct a new power plant to use available flow in the river assuming the existing plant power could be increased.

c) Construct a new power plant to use the available flow in the river assuming the existing plant power could not be increased.

\section{Increase Power of Existing Unit}

The manufacturer of the existing unit was the S. Morgan Smith Company, which subsequently has become part of the Allis Chalmers organization.

Inquiries were made of Allis-Chalmers requesting their review of the potential for increasing the power output of the existing unit by replacing the rotating parts. This unit was designed in 1936-37. Cost data was also requested.

\section{The following details were received:}

Two methods of upgrading power are feasible, new runner blades or alternately a new runner hub with new blades. For each method the increase in power output would be dependent on tailwater elevation. Anticipated power increases and cost, assuming tailwater elevations were not affected by discharge, were stated as follows: 


\section{Tail Water Elevation}

-4.0 feet

0 feet

+4.0 feet

Cost to Manufacture
Horsepower Change New Blades Only

$-1.9 \%$

$+6.48$

$+15.4 \%$

$\$ 155,000$
Horsepower Change New Hub and New'Blades

$+5.18$

$+14.18$

$+21.8 \%$

A review of the power plant operating records reveals that tailwater elevations are normally in the range of 0.0 to 6.0 feet depending on tide level and river flow, thus, the case of power loss is not of practical consequence. What is of consequence, however, is the rapid loss of head due to the rise in tailwater elevations as unit discharge increases, and also the potential for a drop in the headwater pond level due to increased flow through the restriction in the waterway caused by the bridge immediately upstream. These losses are discussed in greater detail in subsequent paragraphs in this appendix.

Generator capacity appears to be ample as its original design was for $9500 \mathrm{kVA}$ at 0.7 power factor. Preliminary analysis indicate that an average increase in power of up to $20 \%$ could be achieved if no head were lost: For each 1 foot of head loss a reduction in power of approximately 2.5\% would occur. Also from the flow duration curve (Figure 7 of the report) the additional water required to give this added power is only available approximately $40 \%$ of the time.

From the above, and assuming turbine maximum efficiency remains unchanged, the approximate maximum energy gain was estimated to be in the range 3000 to $4000 \mathrm{MW}$ hrs. per year.

Order of magnitude estimates of the cost of freight, installation and manufacturers erection supervision together with owners costs and contingencies were prepared, and in the case of upgrading the existing unit only, the value of energy lost during the "tear-down" period was added.

$$
\text { A I }-2
$$


This resulted in an order of magnitude cost of energy compatible with the cost of incremental energy from a new power plant.

On further review it was noted that should the plant be upgraded after a new plant was built energy would not be lost if the runner replacement were scheduled for the low flow period. Additionally, further savings would be possible if the replacement coincided with the next scheduled overhaul. This unit was completely overhauled in 1972 and considering past experience, the next major overhaul probably will not occur until the 1985-90 period.

It was therefore decided to proceed with the study on the basis of developing an optimum design for a new power plant and deferring, until after this plant is operational, the decision on upgrading of the existing unit. After the new unit is installed the estimated maximum annual energy gain will be approximately 1500 to $2000 \mathrm{MW}$ hrs.

Further study was thus concentrated on development of new power plant to use the available flow in the river assuming the existing plant power could not be increased, (i.e., basic case (c) as discussed above).

\section{New Power Plant Studies}

Initially the planning for new power plant was concentrated on the east channel area adjacent to the existing plant as it was considered that in this location the length of headrace and tailrace works could be minimized. Additionally, the new plant would be adjacent to the existing control room and switchyard thus minimizing the length of control and transmission cables and simplifying plant surveilance. A review of the hydraulics of the approach and discharge channels at the existing plant and the automatic water level recording charts which operate continuously revealed some adverse conditions. When the existing unit is brought on line the tailwater rises rapidly especially at low tide. The loss of head of up to 4 feet occurs within 10 to 15 minutes after startup. It was therefore concluded that a hydraulic control exists nearby in the tailwater channel. 
In the forebay pond the approach channel to the existing power plant is restricted in width by the abutments and central pier of the road-rail bridge immediately upstream. Substantial deepening of this channel has already been performed. From the drawings it was concluded that any further improvements to this channel would require major changes to the bridge thus making this a nonviable option. CMP also reported that during fast startup of the existing unit a noticeable forebay drawdown occurs.

In view of the preceding, it was concluded that locating a new plant in the east channel would increase the flows sufficiently to create undesirable head losses for both the proposed and the existing plant. Therefore, further study of locating a new power plant in the east channel was abandoned. The option however, of later increasing the power output of the existing unit would remain under study.

In reviewing potential power plant locations and arrangements, it was determined that the existing West Channel Dam should be incorporated as the headworks of a new project as the cost of a new dam would be prohibitive.

\section{Power Waterways}

Due to topography, and in order to develop äs" much of the available head as possible this required that a new plant would have to have a relatively long intake and/or discharge waterways.

Initially pressure pipelines and an excavated tailrace channel were considered. However for the volume of water under consideration the pressure pipelines would be in the order of one 18 feet diameter pipe or two 13 foot diameter pipes. In the two pipe case submergence requirements on the pipe at the intake would dictate that the invert of the pipe be located at approximately elevation +18 feet, or below, in order to maintain generation during periods of flash board loss. Examination of sounding of the rock surface upstream of the West Channel Dam shows the existing surface to be at elevation +36 feet or above. Thus in order to construct a pipeline intake, large quantities of excavation upstream of the West Channel Dam would be required. To achieve this while maintaining flow to the existing 
power plant and other water users would require a relatively large cofferdam thus increasing cost.

In view of the relatively shallow depth of water upstream of the West Channel Dam the possibility of constructing an open flume to convey water to the powerhouse was examined. After review of preliminary comparative cost estimates and head losses in the alternate schemes it was decided that the open flume would be the most viable alternative.

\section{Powerhouse Location}

Having decided that the new power plant would be in the West channel of the Saco River, access for construction and operation and maintenance dictated that the power plant be located in or adjacent to the right (Biddeford) or left (Saco) bank of the river channel.

It can be seen on Figure 9. of the report that immediately downstream of the West Channel Dam the Biddeford bank is almost. entirely lined with large factory buildings while on the Saco bank only one structure is built against the river bank.

If the power plant were located on the Biddeford side only one point of access is available thus dictating the location of the powerhouse. Additionally as it was considered that a new plant should be operated remotely from the existing control room it would be necessary to cross the river with all control cables.

The Saco side was reviewed and found to offer much greater flexibility in locating the powerhouse while providing better access for construction, operation and maintenance and for trash removal while also being more readily accessible from the existing control room. Several potential points of connection to the distribution system were also available.

Therefore, it was decided that the power plant should be located near the left bank of the river in the City of Saco. 
Further review of the left bank site showed that the water intake flume for the Saco Tannery was constructed in the left bank with its intake adjacent to the abutment of the West Channel Dam. This covered flume is still in use, thus, if disturbed during construction an alternate source of water supply to the factory would have to be provided.

Therefore, it was decided to locate the new power plant in the river bed as close to the bank as possible.

In locating the power plant along the river consideration was given to minimizing the combined total cost of excavating the tailrace channel in rock and constructing the open flume. As the power plant is moved upstream the tailrace excavation deepens and thus becomes more expensive, whereas, the cost for the open flume decreases uniformly. From this cost study it was found to be economical to move the power plant as far upstream as possible. Therefore, the final selected location (see Figure 9 of the report) was governed by the criteria to maintain adequate access without interfering with the existing building and providing adequate space in the flume wall for the new flashboards.

Generating Equipment

As the available head is less than 50 feet it is essential to consider the use of the standardized range of horizontal tube type propeller turbine generator packages presently being developed by a domestic manufacturer. Similar standardized packages are available from several foreign manufacturers.

For the range of flow being considered even the maximum size of standardized units would not be large enough to develop all the power in one unit. It was thus considered prudent to compare the relative merit of a two unit standarized installation with a one unit custom designed vertical shaft propeller installation.

Cost and delivery time data was requested from the manufacturers for both standardized units and a large custom designed unit. The custom designed unit would be similar in concept and size to the existing unit. 
Other types of turbines such as Francis, cross flow, stra-flow and bulb are not considered to be viable alternatives for this site.

Due to the fact that daily storage is available at the site, both fixed blade propeller and adjustable blade propeller units were considered.

The standard tube turbine does not have wicket gates. If the runner has fixed blades the generator must be the induction type. Water flow control for startup and shutdown is by the inlet valve. This system has been tried at a plant in wisconsin and, reportedly, is not completely satisfactory. The adjustable blade turbine provides flow control during startup and shutdown by adjusting the blade setting, and permits use of a synchronous generator.

From the cost analysis it was determined that the generating equipment cost for one custom designed unit as compared to two standardized units was almost identical for equivalent total capacity. A review of the other power plant costs indicated that the single custom designed unit would require more complex concrete formwork for both the semi-spiral case, its intake, and the draft tube elbow. Also intake gates would be much larger and the tailrace excavation would have to be deeper. Delivery time for the standardized units was substantially less.

It was concluded that the overall cost of the equipment and structure for the two standardized design units would be lowest. In addition the standardized unit uses a speed increasing gearbox between the turbine and generator allowing the use of a smaller, high speed, generator. 'This reduces the maximum weight required to be handled during erection and maintenance. Although speed increasing gearboxes have been used on small vertical units it is not a feature that has been offered by domestic manufacturers, thus the benefits of generator weight reduction due to increased speed would not be realized with the vertical unit.

Subsequently work was based on the assumption that two standardized horizontal tube type propeller units would be specified. 
In determining if the unit should be fixed blade or adjustable blade a study was made of the added energy that could be obtained from the adjustable blade turbine due to its ability to be driven at overload during the approximately $20 \%$ of the time that flow is in excess of the total plant capacity. This increment of energy was then evaluated against the increased cost of the adjustable blade turbine as compared to the fixed blade turbine. The results of this study summarized in Appendix II indicate the adjustable blade turbine to be the most economic. 


\section{APPENDIX II}

\section{Alternative Capacity, Energy, Cost Studies}

After the basic layout of the new power plant had been determined and the use of horizontal standardized tube type turbines had been decided (see Appendix I) a study was made to optimize the installed capacity and evaluate the difference between an adjustable blade turbine with a synchronous generator and a fixed blade turbine with an induction generator.

On the basis of preliminary analysis a range of turbine sizes was selected. For each size, capacity was estimated and the possible energy generation was determined as discussed in section E III of the report.

The results of this analysis are shown in Table A II-I.

For each case a cost estimate was prepared compatible with the cost estimate discussion in section $F$ of this report.

These values were then used to perform an economic analysis which is discussed in Section $\mathrm{G}$ of this report. 
CENTRAL MAINE POWER COMPANY

CATARACT HYDROELECTRIC DEVELOPMENT

EXPANSION STUDY

\section{ALTERNATE STUDIES - CAPACITY vS ENERGY}

\begin{tabular}{|c|c|c|c|c|c|c|c|c|}
\hline \multicolumn{9}{|c|}{ AVERAGE ENERGY (MWhr) } \\
\hline TWO UNITS & \multicolumn{4}{|c|}{ ADJUSTABLE BLADE } & \multicolumn{4}{|c|}{ FIXED BLADE } \\
\hline TURBINE SIZE $(\mathrm{mm})$ & 3000 & 2750 & 2500 & 2250 & 3000 & 2750 & 2500 & 2250 \\
\hline MAX. CAPACITY $(k W)$ & 10140 & 8780 & 7500 & 5950 & 8400 & 7300 & 6240 & 4950 \\
\hline JAN. & 760 & 730 & 680 & 620 & 720 & 680 & 630 & 560 \\
\hline FEB. & 610 & 590 & 560 & 500 & 580 & 550 & 520 & 460 \\
\hline MAR. & 1,890 & 1,750 & 1,610 & 1,410 & $i, 710$ & 1,580 & 1,440 & 1,240 \\
\hline APR. & 6,220 & 5,510 & 4,790 & 3,870 & 5,240 & 4,620 & 4,000 & 3,210 \\
\hline MAY & 5,090 & 4,590 & 4,070 & 3,370 & 4,410 & 3,950 & 3,480 & 2,850 \\
\hline JUN. & 1,340 & 1,280 & 1,190 & 1,060 & 1,260 & 1,180 & 1,090 & 940 \\
\hline JUL. & 270 & 250 & 230 & 200 & 240 & 230 & 210 & 180 \\
\hline AUG. & 100 & 100 & 100 & 100 & 110 & 100 & 100 & 90 \\
\hline SEP. & 170 & 160 & 150 & 130 & 150 & 140 & 130 & 110 \\
\hline OCT. & 320 & 310 & 290 & 260 & 300 & 290 & 270 & 240 \\
\hline NoV. & 1,150 & 1,090 & 1,020 & 900 & 1,070 & 1,000 & 920 & 800 \\
\hline DEC. & 1,430 & 1,330 & 1,220 & 1,050 & 1,290 & 1,190 & 1,080 & 920 \\
\hline ANNUAL & 19,360 & 17,680 & 15,910 & 13,470 & 17,090 & 15,520 & 13,850 & 11,610 \\
\hline
\end{tabular}




\section{APPENDIX III}

\section{Geological Reconnaissance and Subsurface Exploration Log}

Bedrock, which is exposed in the valley section of the Saco River is considered competent and sound and will provide a suitable foundation for the proposed power plant and other structures.

Figure AIII-I shows the location of a subsurface borehole taken in the vicinity of the proposed power plant. A $\log$ of this borehole is also attached.

Exposed bedrock is considered to be part of the Kittery formation of Lower Silurian age. The most common and characteristic lithology is a medium purplish, gray, hard, brittle, fine grained quartzite occurring in medium to thick $\left(I^{\prime}-4^{\prime}\right)$ beds with some thin bedded quartzite which includes interbeds of phyllite. Calcite or Dolomite is also present in small amounts in most exposures, but the rock is in general too finegrained to determine megascopically the other minerals present.

The strike of the beds is generally $N 65^{\circ} \mathrm{W}$ and dip $60^{\circ}$ towards $\mathrm{NE}$.

The following three types of joints were observed in the exposed bedrock of the river.
a) Strike $\mathrm{N} 55^{\circ} \mathrm{W}$ dip $60^{\circ} \mathrm{NE}$ (bedding joint) Spacing 6" to $2^{\prime}$
b) $\mathrm{N} 47^{\circ} \mathrm{E}$ dip $67^{\circ} \mathrm{NW}$ spacing $l^{\prime}$ to $5^{\prime}$
c) $\mathrm{N} 45^{\circ} \mathrm{W}$ dip $50^{\circ} \mathrm{SW}$ spacing. $2^{\prime}$ to $5^{\prime}$

In the borehole rock was encountered at 28 feet depth. No samples were taken in the overburden as it appears to be fill material which is consistant with the location and height of the adjacent stone retaining wall. It consisted of sand and gravel with some silt.

Beärock predominately consists of gray, fine grained, hard quartzite having interbeds of phyllite at places with frequent calcite veins and occasional quartz veins. It was mostly sound and fresh with a few highly 
fractured zones particularly in Phyllite. Rock Quality Designation (RQD) for $50 \%$ of the rock is more than $80 \%$ and $75 \%$ of the core has RQD of more than $60 \%$. Joint spacing is $4^{\prime \prime}$ to $12^{\prime \prime}$ with dip ranging from $35^{\circ}$ to $65^{\circ}$.

At the borehole location the ground surface is at approximately elevation +32 feet. This places the bottom of the borehole at approximate elevation -29.5 feet which is well below the base of the power plant.

The drilling was carried out by Marine Test Boring Company using a C-34 mobile drill and an NX C-3 wireline core barrel under the supervision of a TAMS geologist. 


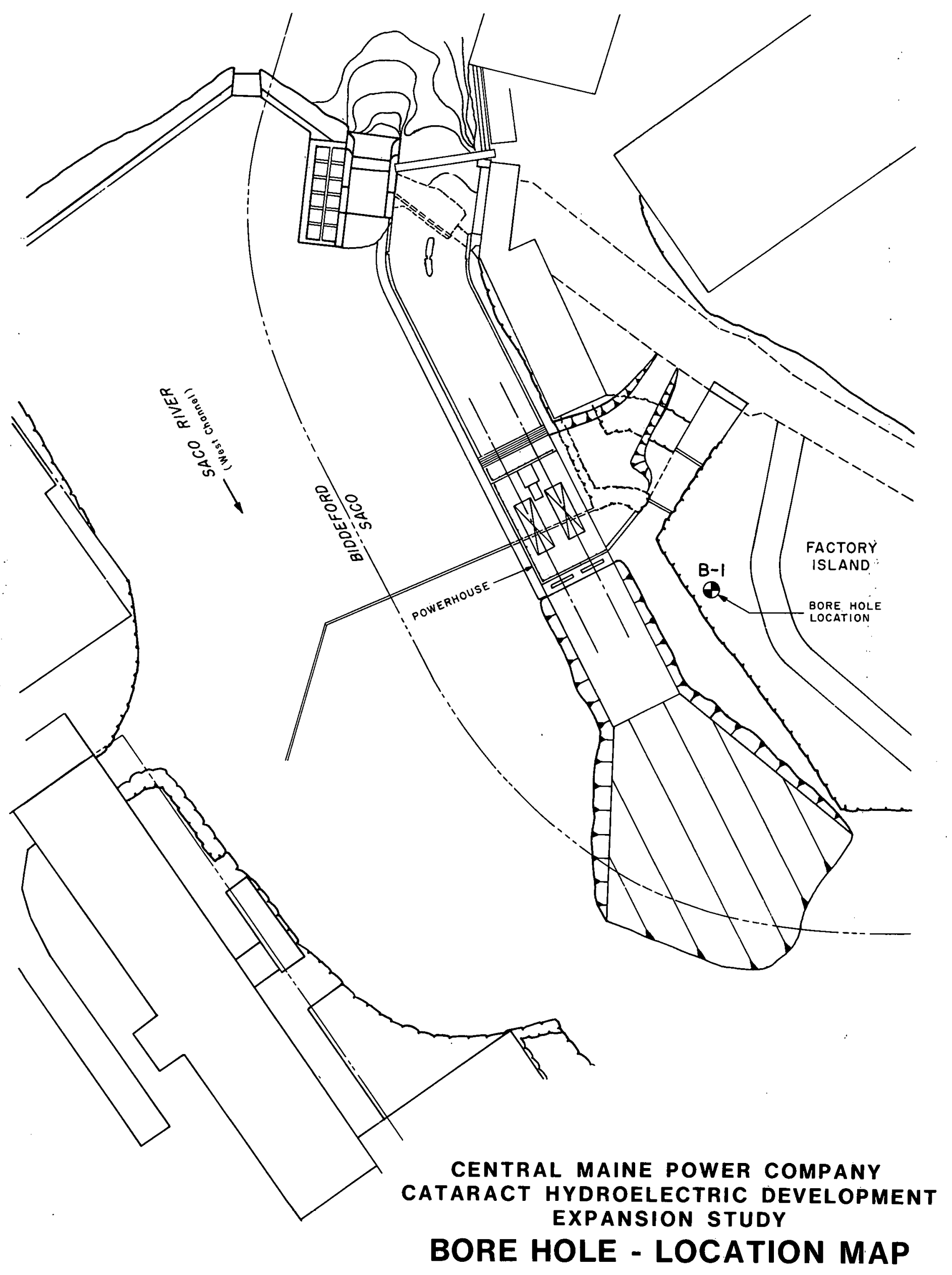


JOB NO. 3350 JOo TITLE Catoract Hydroelectric plant, Sace Maine LOCATIONEAf Bank, Sace River COORDINATES 24I118ON/ DRILL Mebile C-34 angLe Yertical REFERENCE ELEV. DATUM. DRILL ING contractor Maine Test Boring. Ine DRILLER Dex wiswell IN. CASING HAMMER: WT. INSPECTOR M.AKbOX SAMPLE HAMER: WT. LBS. DROP

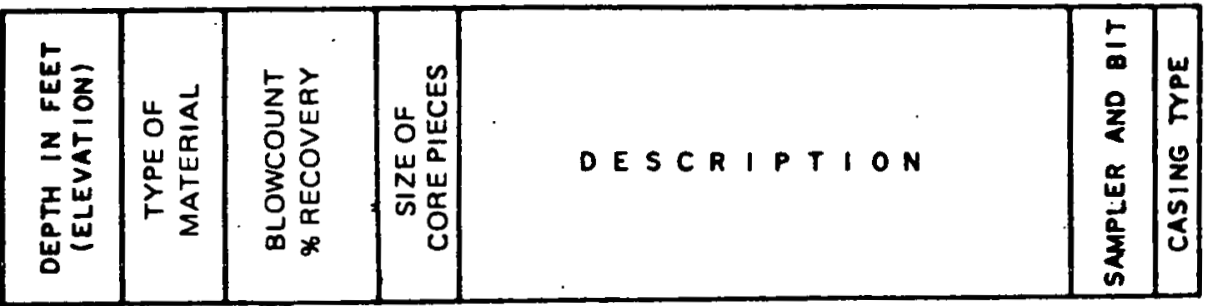

\begin{tabular}{|c|c|c|c|c|c|}
\hline 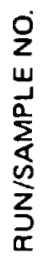 & $\begin{array}{l}\frac{I}{5} \\
\stackrel{+}{W} \\
\end{array}$ & 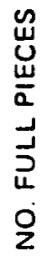 & 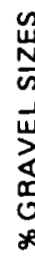 & $\underset{x}{\partial}$ & 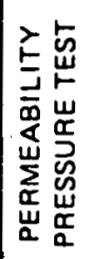 \\
\hline
\end{tabular}

LBS. DROP IN.

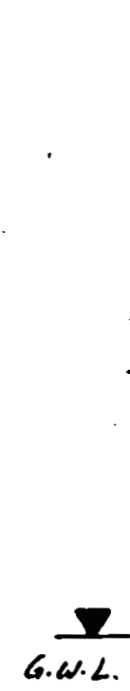

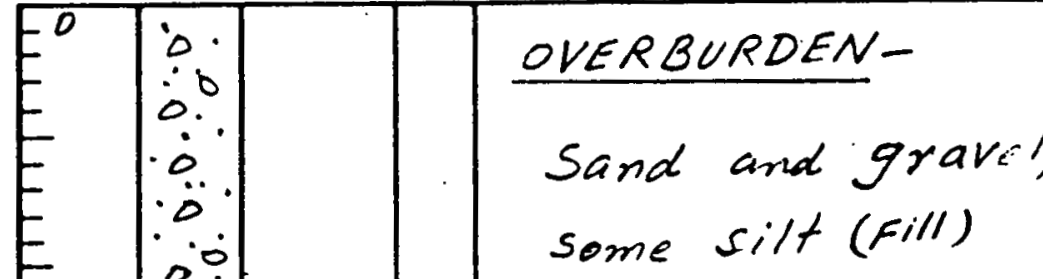

E E $25 \mid \begin{array}{cc}0 \\ 0 \\ 0 \\ 0 \\ 0 \\ 0 \\ 0 \\ 0 \\ 0 \\ 0 \\ 0\end{array}$

G.W.L.

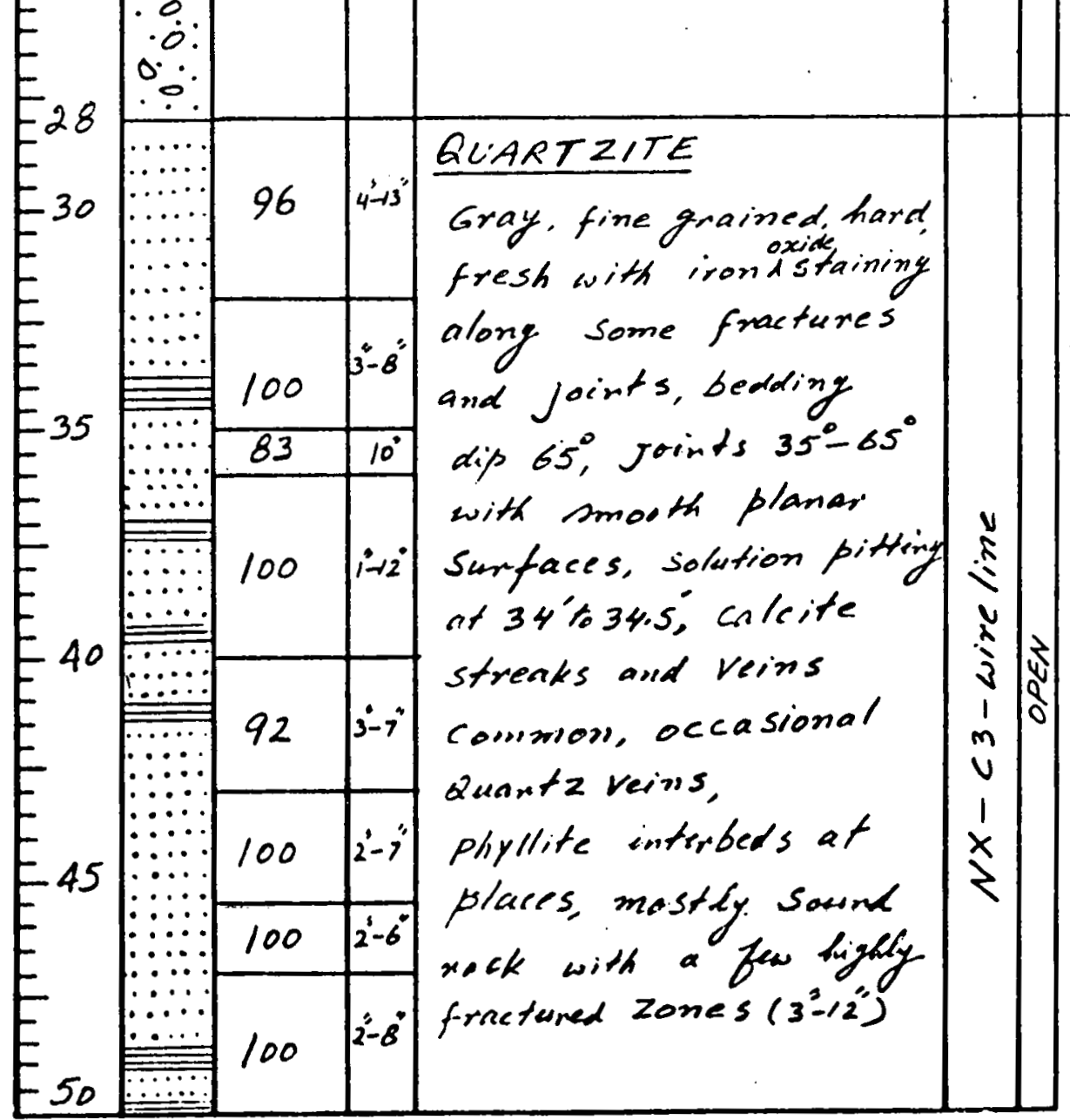

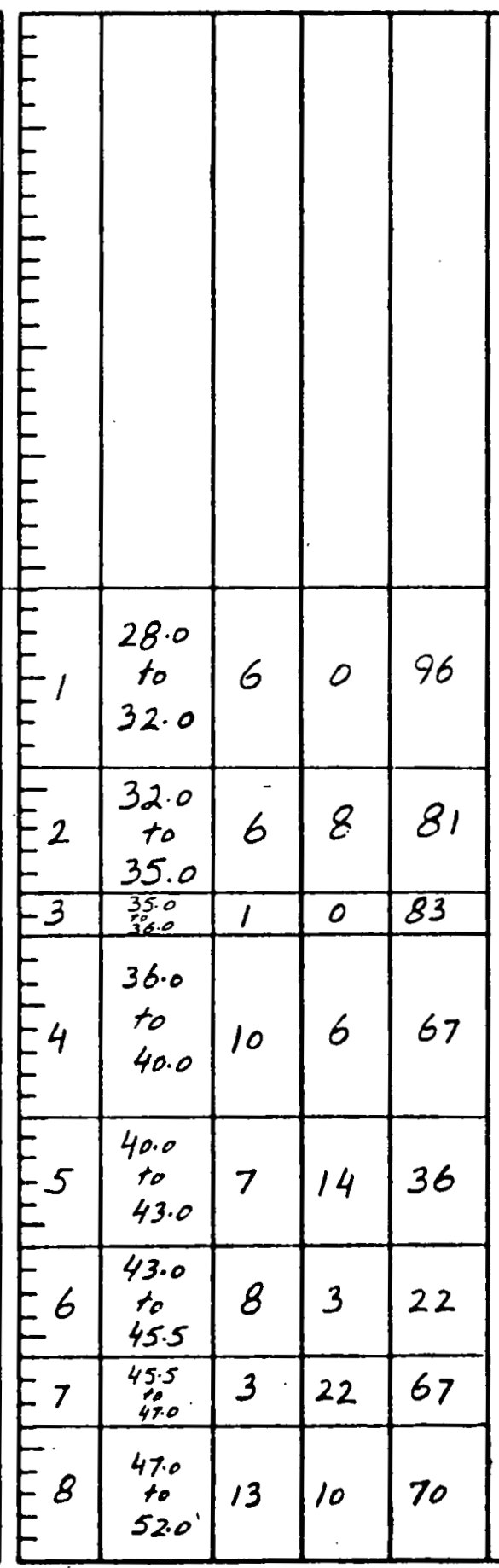


JOB NO. 3350 JoB TITLE Cataract Hydreclectrie plant LOCATION Left Bank, Sace River cooroinates $241180 \mathrm{~N} / 424200$ E(APProx) DATE $11 / 19$ to $11 / 21 / 78$ DriLl Mebile C-34 angle Vertical reference elev. DATUM

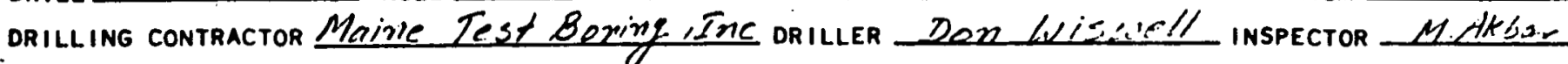
SAMPLE HAMMER: WT. LBS. DROP

IN. CASING HAMMER: WT. LBS. OROP IN.

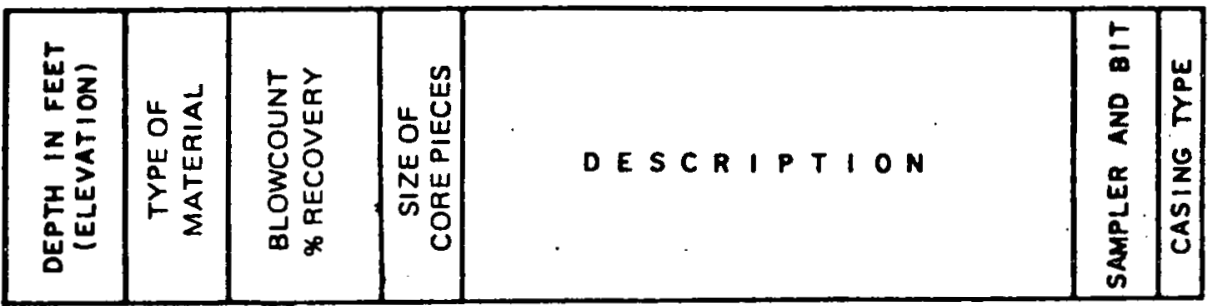

\begin{tabular}{|c|c|c|c|c|c|}
\hline 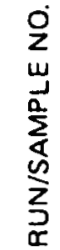 & 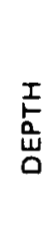 & 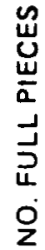 & 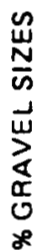 & $\underset{\alpha}{\stackrel{0}{0}}$ & 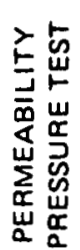 \\
\hline
\end{tabular}

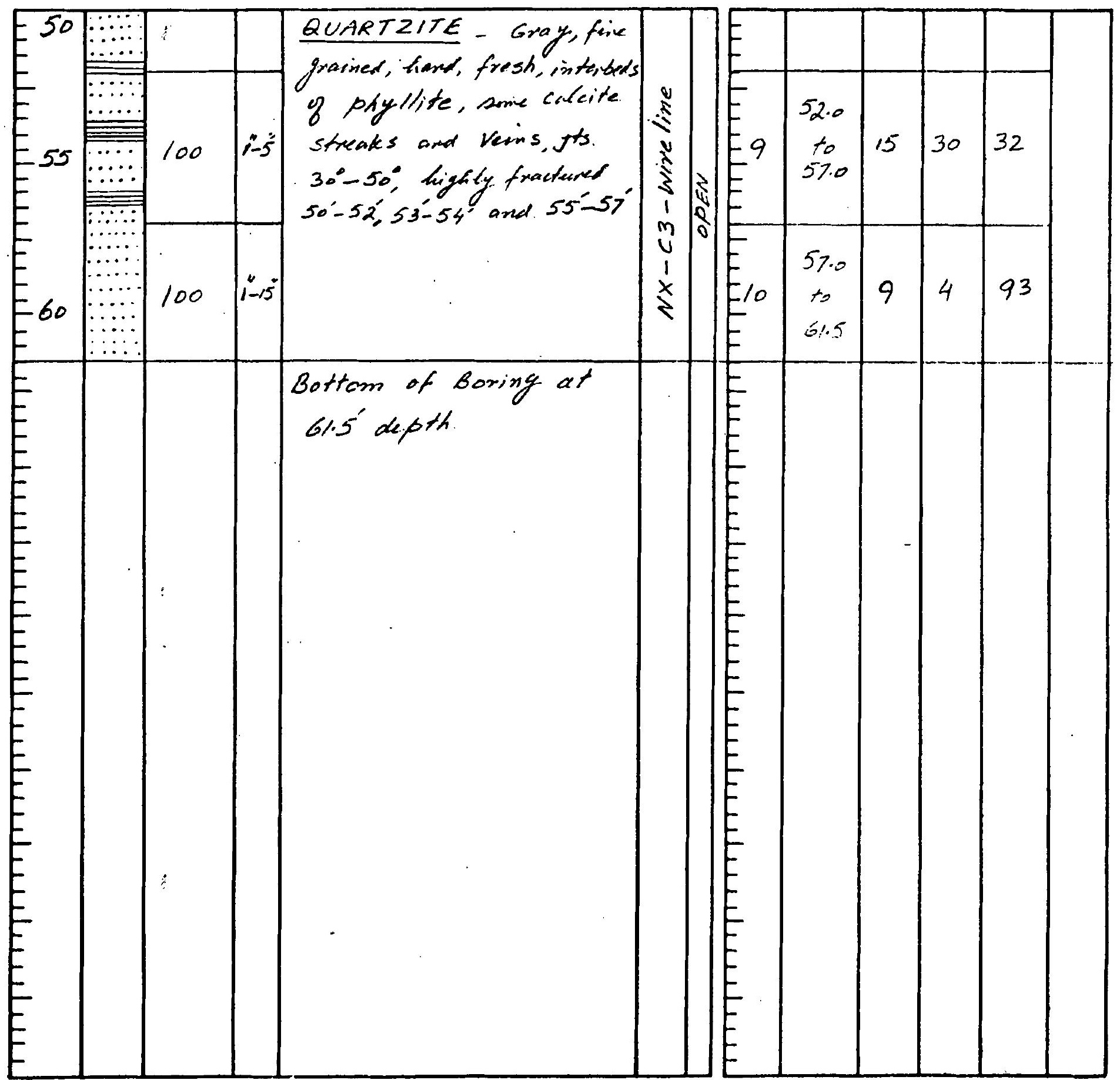

